\begin{tabular}{|c|c|}
\hline Title & Cytotoxic effects of cadmium and zinc co-exposure in PC12 cells and the underlying mechanism \\
\hline Author(s) & $\begin{array}{l}\text { Rahman, Md. Mostafizur; Ukiana, Junki; U son-Lopez, Rachael; Sikder, Md. Tajuddin; Saito, Takeshi; Kurasaki, } \\
\text { Masaaki }\end{array}$ \\
\hline Citation & $\begin{array}{l}\text { Chemico-Biological Interactions, 269, } 41-49 \\
\text { https://doi.org/10.1016/.cbi.2017.04.003 }\end{array}$ \\
\hline Issue Date & $2018-0402$ \\
\hline Doc URL & http:/hdl.handle.net/2115/68652 \\
\hline Rights & $\begin{array}{l}\text { (0) 2017. This manuscript version is made available under the CC-BY-NC-ND } 4.0 \text { license } \\
\text { http://creativecommons.org/icenses/by-nc-nd/4.0/ }\end{array}$ \\
\hline Rights(URL) & http://creativecommons.org/icenses/by-nc-nd/4.0/ \\
\hline Type & article (author version) \\
\hline File Information & Manuscript_CBI R3 fresh.pdf \\
\hline
\end{tabular}

Instructions for use 


\section{Cytotoxic effects of cadmium and zinc co-exposure in PC12 cells and the underlying mechanism}

Md. Mostafizur Rahman ${ }^{1,2}$, Junki Ukiana ${ }^{1}$, Rachael Uson-Lopez ${ }^{1}$, Md. Tajuddin Sikder ${ }^{1,3}$, Takeshi Saito $^{3}$, Masaaki Kurasaki ${ }^{1,4^{*}}$

${ }^{1}$ Graduate school of Environmental Science, Hokkaido University, ${ }^{2}$ Department of

Environmental Sciences, Jahangirnagar University, Bangladesh, ${ }^{3}$ Faculty of Health Sciences, Hokkaido University, ${ }^{4}$ Faculty of Environmental Earth Science, Hokkaido University

*:Address correspondence to:

Dr. Masaaki KURASAKI, Faculty of Environmental Earth Science, Hokkaido University

Sapporo 060-0810, Japan; Phone: +81-11-706-2243, Fax: +81-11-706-4864; Email:kura@ees.hokudai.ac.jp

\footnotetext{
Abbreviations;

amyotrophic lateral sclerosis, ALS; copper-zinc superoxide dismutase, Cu/Zn-SOD; reactive oxygen species, ROS; glutathione, GSH; bovine aorta endothelial cells, BAECs; metallothionein, MT; lactate dehydrogenase, LDH; mitochondrial membrane potential, MMP; mitochondrial permeability transition, MPT; voltage-dependent anion channel, VDAC
} 


\begin{abstract}
Cadmium $\left(\mathrm{Cd}^{2+}\right)$ is a well studied inducer of cellular necrosis and apoptosis. Zinc $\left(\mathrm{Zn}^{2+}\right)$ is known to inhibit apoptosis induced by toxicants including $\mathrm{Cd}^{2+}$ both in vitro and in vivo. The mechanism of $\mathrm{Zn}^{2+}$-mediated protection from $\mathrm{Cd}^{2+}$-induced cytotoxicity is not established. In this study, we aimed to understand the effects of $\mathrm{Zn}^{2+}$ on $\mathrm{Cd}^{2+}$-induced cytotoxicity and apoptosis using PC12 cells. Cell viability and DNA fragmentation assays in PC12 cells exposed to $\mathrm{Cd}^{2+}$ and/or $\mathrm{Zn}^{2+}$ revealed that $\mathrm{Cd}^{2+}$ (5 and $10 \mu \mathrm{mol} / \mathrm{L}$ ) alone induced significant cell death, and co-exposure to $\mathrm{Zn}^{2+}(5,10$, and $100 \mu \mathrm{mol} / \mathrm{L})$ for $48 \mathrm{~h}$ had a protective effect. Assessment of intracellular free sulfhydryl levels and lactate dehydrogenase activity suggested that $\mathrm{Cd}^{2+}(10$ $\mu \mathrm{mol} / \mathrm{L}$ ) induced oxidative stress and disrupted cell membrane integrity. Addition of $\mathrm{Zn}^{2+}$ (10 and $100 \mu \mathrm{mol} / \mathrm{L}$ ) reduced $\mathrm{Cd}^{2+}$-mediated cytotoxicity. Changes in expression of the apoptotic factors Bax, Bcl-2, Bcl-x, and cytochrome c were measured via western blot and expression of caspase 9 was detected via reverse transcriptase polymerase chain reaction. Western blots showed that $\mathrm{Zn}^{2+}(10$ and $100 \mu \mathrm{mol} / \mathrm{L})$ suppressed $\mathrm{Cd}^{2+}$-induced apoptosis $(10 \mu \mathrm{mol} / \mathrm{L})$ by reducing cytochrome c release into the cytosol, and downregulating the proapoptotic protein, Bax. In addition, expression of caspase 9 was lower in $\mathrm{Cd}^{2+}(5 \mu \mathrm{mol} / \mathrm{L})$-treated PC12 cells when co-treated with $\mathrm{Zn}^{2+}$ (2 and $5 \mu \mathrm{mol} / \mathrm{L}$ ). These findings suggest that the effective inhibition of $\mathrm{Cd}^{2+}$-induced apoptosis in PC12 cells by $\mathrm{Zn}^{2+}$ might be due to suppression of mitochondrial apoptosis pathway and inhibition of $\mathrm{Cd}^{2+}$-induced production of reactive oxygen species.
\end{abstract}

Keywords: apoptosis, heavy metals, cytochrome c, DNA, caspase 9, glutathione 


\section{Introduction}

Cadmium $\left(\mathrm{Cd}^{2+}\right)$ is one of the most toxic heavy metals due to its prolonged biological half life, low rate of excretion and high accumulation capacity in soft tissues. It is a widespread toxicant of occupational and environmental concern because environmental levels have risen steadily with increased (about 13,000 tons/year) production of $\mathrm{Cd}^{2+}$ for nickel-cadmium batteries, pigments, chemical stabilizers, metal coatings, and alloys [1, 2]. Major sources of human exposure to $\mathrm{Cd}^{2+}$ include i) occupational: primary metal industries, battery production industries, chemical stabilizer industries, among others and ii) non-occupational: cigarette smoking and consumption of contaminated foods and water [1-3]. The toxic effects of $\mathrm{Cd}^{2+}$ have been extensively studied in in vivo and in vitro systems. $\mathrm{Cd}^{2+}$ affects metabolic processes including energy metabolism, membrane transport, and protein synthesis. It may also act on DNA directly or indirectly by interfering with gene control and repair mechanisms [4, 5]. Numerous studies have shown that $\mathrm{Cd}^{2+}$ damages mammalian organs including the lungs, kidneys, testes and the cardiovascular, hematopoietic, and nervous systems [6, 7]. $\mathrm{Cd}^{2+}$ exposure has been reported as a causative factor in the progressive neurodegenerative disorder amyotrophic lateral sclerosis (ALS). The link between Cd2+ exposure and ALS may include reduced neuronal expression of copper-zinc superoxide dismutase (Cu/Zn-SOD) [8]. Occupational $\mathrm{Cd}^{2+}$ exposure was found to negatively affect psychomotor function and memory of workers and cause olfactory dysfunction and neurobehavioral defects $[9,10]$. Increasing evidence indicates that $\mathrm{Cd}^{2+}$ disrupts integrity of the mitochondrial membrane [11]. Recently, it has been shown that $\mathrm{Cd}^{2+}$ can disrupt the bloodbrain barrier and enter the brain $[12,13]$. Neuronal exposure to $\mathrm{Cd}^{2+}$ eventually triggers release of mitochondrial proteins such as cytochrome c into the cytosol. These mitochondrial proteins activate catabolic hydrolases, which cleave important cellular targets resulting in cell death. $\mathrm{Cd}^{2+}$ toxicity may be associated with production of reactive oxygen species (ROS), making mitochondria key targets for $\mathrm{Cd}^{2+}$ toxicity. High levels of ROS have been suggested to increase blood-brain barrier permeability, induce tubulin alterations, and perturb synaptic transmission [9]. It has been proven that $\mathrm{Cd}^{2+}$ can induce apoptosis via the mitochondrial pathway in cell lines [14-16]. At low and moderate concentrations in cell culture systems (e.g., 0.1-10 $\mu \mathrm{mol} / \mathrm{L}$ ), $\mathrm{Cd}^{2+}$ causes apoptosis. At higher concentrations (>50 $\mu \mathrm{mol} / \mathrm{L})$, necrosis becomes evident [17].

Zinc $\left(\mathrm{Zn}^{2+}\right)$ is a well-known essential trace metal belonging to group IIB in the periodic table (as does $\mathrm{Cd}^{2+}$ ), and is a required cofactor for various essential enzymes. By contrast, $\mathrm{Cd}^{2+}$ has no 
known physiological or biochemical functions in organisms [17]. Multiple biological macromolecules contain $\mathrm{Zn}^{2+}$ as a structural component, and $\mathrm{Zn}^{2+}$ is a major regulator of normal human development [18]. According to the Protein Data bank, more than 2700 enzymes, including hydrolases, transferases, oxidoreductases, ligases, isomerases and lyases contain $\mathrm{Zn}^{2+}$ [19]. Additionally, $\mathrm{Zn}^{2+}$ exhibits antioxidant properties and can activate metal-binding proteins/chaperones. It is also capable of binding to and inhibiting oxidation of reduced glutathione (GSH) under oxidative stress conditions [20]. Several studies have reported a therapeutic role of $\mathrm{Zn}^{2+}$ in treating $\mathrm{Cd}^{2+}$ toxicity in vivo and in vitro. For example, $\mathrm{Zn}^{2+}$ inhibits $\mathrm{Cd}^{2+}$-induced apoptosis and ROS production in HeLa cells and bovine aorta endothelial cells (BAECs) [16, 21]; $\mathrm{Zn}^{2+}$ supplementation improves biochemical characteristics of distal femur and femoral diaphysis in male rats chronically exposed to $\mathrm{Cd}^{2+}$ [22]. Enhanced $\mathrm{Zn}^{2+}$ consumption prevents alterations in lipid metabolism induced by $\mathrm{Cd}^{2+}$ in male rats [23]; and $\mathrm{Zn}^{2+}$ protects rats against $\mathrm{Cd} 2+$-induced hepatotoxicity [24]. $\mathrm{Zn}^{2+}$ affects some enzymes involved in DNA metabolism and inhibits apoptosis via its effect on transcriptional factors activated during apoptosis [25]. Studies have shown that $\mathrm{Zn}^{2+}$ plays a crucial role in maintenance of the cellular redox balance via several molecular mechanisms, including modulation of oxidant production and oxidative damage [26], regulation of GSH metabolism, induction of metallothionein (MT), and scavenging of oxidants [27].

The effects of $\mathrm{Zn}^{2+}$ discussed above led us to test the hypothesis that $\mathrm{Zn}^{2+}$ might have critical regulatory effects on the pathways through which $\mathrm{Cd}^{2+}$ induces toxicity in PC12 cells. The presence of multiple metals in the environment and biological systems, and the possibility of simultaneous exposure to multiple metals have led to an increased interest in these studies. Currently, cytological and in vivo studies on the effects of simultaneous exposure to similar compounds, such as $\mathrm{Cd}^{2+}$ and $\mathrm{Zn}^{2+}$, are limited. PC12 cell line is a rat pheochromocytoma clonal cell line, which has been used as a neuron model in molecular biology. $\mathrm{Cd}^{2+}$ is considered a potential etiological factor in neurodegenerative diseases [15], and the PC12 cell line has been selected as a neuron model to study the underlying mechanisms. The objective of this study was to understand the effects of $\mathrm{Zn}^{2+}$ on $\mathrm{Cd}^{2+}$-induced toxicity, and to investigate its regulatory role in mechanisms underlying $\mathrm{Cd}^{2+}$-induced apoptosis in PC12 cells. Finally, we aimed to unveil the underlying molecular mechanism by which $\mathrm{Zn}^{2+}$ inhibits $\mathrm{Cd}^{2+}$-induced apoptosis after coexposure by measuring cell viability, DNA integrity, leakage of lactate dehydrogenase, 
intracellular levels of GSH, and changes in expression of apoptotic factors at the mRNA and protein level using PC12 cells.

\section{Materials and methods}

\subsection{Materials}

PC12 cells were purchased from the American Type Culture Collection (USA and Canada). Dulbecco's modified Eagle's medium (DMEM), ribonuclease A (RNase), ethidium bromide, and peroxidase-conjugated avidin were purchased from Sigma (St. Louis, MO, USA). Fetal bovine serum (FBS) was bought from HyClone (Rockville, MD, USA). SV total RNA isolation system and RT-PCR kit were purchased from Promega (Madison, WI, USA). High pure PCR product purification kit and proteinase K were purchased from Roche Diagnostics (Mannheim, Germany). Biotinylated goat anti-mouse IgG whole antibody and ECL western blotting detection reagent were purchased from Amersham Pharmacia Biotech (Buckinghamshire, England). Polyclonal antibodies against Bcl-2 (Cat\#PC68, Oncogene), Bax (BIS, bs-0127R, BIOSS), beta-actin (GTX 109639, GeneTEX) were purchased. Anti-cytochrome c monoclonal antibody was purchased from BD Biosciences Pharmingen (San Jose, CA, USA). Trypan blue solution (0.4\%) was purchased from Bio-Rad (Hercules, CA, USA). The DNA 7500 assay and RNA 6000 nano assay kits were purchased from Agilent Technologies (Waldbronn, Germany). All other chemicals were of analytical grade.

\subsection{Cell culture}

PC12 cells were cultured in DMEM supplemented with 10\% FBS in a humidified incubator at $37{ }^{\circ} \mathrm{C}$ with $5 \% \mathrm{CO}_{2}$. The cells were pre-incubated in $25-\mathrm{cm}^{2}$ flasks for $24 \mathrm{~h}$; then, the medium was replaced with serum/serum-free DMEM with or without various concentrations of $\mathrm{CdCl}_{2}$ and $\mathrm{ZnCl}_{2}$, or with a mixture of both chemicals, and the cells were incubated for $48 \mathrm{~h}$. When the medium was replaced with serum-free medium, cells were washed twice with serum-free DMEM. The desired concentration for treatment was selected by exposing PC12 cells to $\mathrm{Cd}^{2+}(0$, 2, 5, 10, $20 \mu \mathrm{mol})$ and $\mathrm{Zn}^{2+}(0,2,5,10,20,100$, and $500 \mu \mathrm{mol})$ separately, and then the final combination was decided. The selected concentration for $\mathrm{Cd}^{2+}$ was $10 \mu \mathrm{mol}$, whereas $\mathrm{Zn}^{2+}$ was used at 10, 100, and $500 \mu \mathrm{mol}$. 


\subsection{Cell viability}

Cell viability was determined using trypan blue exclusion assay. PC12 cells were seeded at a density of $1 \times 10^{5}$ cells/flask and pre-incubated for $24 \mathrm{~h}$. Then, the cells were treated with $\mathrm{Cd}^{2+}$ (0, 2, 5, 10, and $20 \mu \mathrm{mol} / \mathrm{L}$ and 0, 5, 10, 100, and $500 \mu \mathrm{mol} / \mathrm{L})$ and $\mathrm{Zn}^{2+}(0,2,5,10$, and 20 $\mu \mathrm{mol} / \mathrm{L}$ and 10,100 , and $500 \mu \mathrm{mol} / \mathrm{L})$ separately; in addition, they were co-exposed to $\mathrm{Cd}^{2+}(10$ $\mu \mathrm{mol} / \mathrm{L})$ and $\mathrm{Zn}^{2+}(10,100$, and $500 \mu \mathrm{mol} / \mathrm{L})$. The cells were then incubated for $48 \mathrm{~h}$. Total cells and trypan blue-stained cells were counted using a Bio-Rad automated cell counter (Hercules, CA, USA). Cell viability was expressed as percentage of the counted trypan blue-stained cells. Each experiment was carried out at least in triplicate to ensure biological reproducibility and statistical validity.

\subsection{Cytotoxicity assay}

\subsubsection{Lactate dehydrogenase (LDH) activity assay}

Cytotoxicity was assessed by measuring the activity of LDH in the treatment medium using a nonradioactive cytotoxicity assay kit (Promega) as described by Kihara et al. [28]. PC12 cells (1 $\times 10^{5}$ cells/flask) were cultured in the medium with/without $\mathrm{Cd}^{2+}(0,10 \mu \mathrm{mol} / \mathrm{L})$ or $\mathrm{Cd}^{2+}(10$ $\mu \mathrm{mol} / \mathrm{L})+\mathrm{Zn}^{2+}(10,100$, and $500 \mu \mathrm{mol} / \mathrm{L})$ for $48 \mathrm{~h}$. After 48-h incubation, $50 \mu \mathrm{L}$ of the medium was transferred to a $1.5-\mathrm{mL}$ tube, and then $50 \mu \mathrm{L}$ of a substrate mixture containing tetrazolium salts was added to the tube. After 30 -min incubation at room temperature $\left(25^{\circ} \mathrm{C}\right), 50 \mu \mathrm{L}$ of the stop solution was added, and the amounts of formazan dye formed were determined by measuring the absorbance at $490 \mathrm{~nm}$ using a DU-65 spectrophotometer (Beckman, CA, USA). LDH activity was expressed as LDH activity/ $1 \times 10^{6}$ cells. This experiment was carried out in triplicate for ensuring reproducibility.

\subsubsection{Measurement of intracellular free sulfhydryl (SH) levels}

Intracellular free SH levels were investigated as previously described by Kihara et al. [28]. Cells $\left(1 \times 10^{5}\right)$ were pre-incubated for $24 \mathrm{~h}$. Then, they were exposed to $\mathrm{Cd}^{2+}(10 \mu \mathrm{mol} / \mathrm{L})$ or $\mathrm{Cd}^{2+}(10 \mu \mathrm{mol} / \mathrm{L})+\mathrm{Zn}^{2+}(10-500 \mu \mathrm{mol} / \mathrm{L})$ for $48 \mathrm{~h}$. The cells were harvested, washed with $1 \times$ phosphate-buffered saline (PBS), added to $150 \mu \mathrm{L}$ of a lysis buffer, and then incubated at room temperature $\left(25^{\circ} \mathrm{C}\right)$ for $10 \mathrm{~min}$. Two freeze-thaw sonication cycles were performed in order to rupture the cell membranes, and the resultant solution was centrifuged at 1,500 rpm for 10 min to collect the supernatant. The total protein contents were measured spectrophotometrically by 
using protein assay dye reagent (Bio-Rad, Hercules, CA, USA). Intracellular free SH levels were determined using $2.5 \mu \mathrm{mol} / \mathrm{L}$ 5,5'-dithiobis-2-nitrobenzoic acid (DTNB, pH 7). DTNB (final concentration; $200 \mu \mathrm{mol} / \mathrm{L}$ ) was added to the cell lysate, and then the absorbance was measured at $412 \mathrm{~nm}$ by using a DU-65 spectrophotometer (Beckman, CA, USA). The concentration of free SH in PC12 cells was determined using a molecular coefficient factor of 13,600 per cell number $\left(1 \times 10^{5}\right)$. The experiment was carried out in triplicate to ensure mechanical reproducibility.

\subsection{Isolation of genomic DNA from PC12 cells}

After treatment of PC12 cells with various concentrations of $\mathrm{CdCl}_{2}$ and $\mathrm{ZnCl}_{2}$, the genomic DNA was isolated using high pure PCR template preparation kit according to the manufacturer's instruction as described by Kawakami et al. (2008) [29]. After 48-h incubation, the cells were harvested using a scraper. Then, the obtained cells were centrifuged at 1,500 rpm for 5 min to remove the supernatant. After addition of $3 \mathrm{~mL}$ of PBS, the mixture was centrifuged again at 1,500 rpm for 5 min to wash the cells. The obtained solution containing DNA was mixed with 2 $\mu \mathrm{L}$ of $500 \mu \mathrm{g} / \mathrm{mL}$ RNase and incubated for $15 \mathrm{~min}$ at $37^{\circ} \mathrm{C}$. After incubation, $500 \mu \mathrm{L}$ of ethanol and $20 \mu \mathrm{L}$ of $3 \mathrm{M} \mathrm{NaOAc}$ buffer ( $\mathrm{pH}$ 4.5) were added for ethanol precipitation, and the solution was allowed to stand overnight in a freezer to precipitate the DNA. On the next day, DNA was separated using microcentrifugation at 15,000 rpm for $8 \mathrm{~min}$, and then washing with 70\% ethanol at the same speed for 3 min was carried out. Then, the DNA sample was dried for approximately 10 min, and DNA concentration was measured after reaction with $1 \times$ Tris/Borate/EDTA (TBE) using a UV-visible spectrophotometer.

\subsection{Agarose gel electrophoresis of genomic DNA}

The ladder pattern of DNA was analyzed via agarose gel electrophoresis. The DNA was collected from PC12 cells after treatment with $\mathrm{Cd}^{2+}(0,2,5,10$, and $20 \mu \mathrm{mol} / \mathrm{L})$ and $\mathrm{Zn}^{2+}(0,2,5$, 10, and $20 \mu \mathrm{mol} / \mathrm{L}$ ) for $48 \mathrm{~h}$. Approximately 3-5 $\mu \mathrm{g}$ of DNA with the loading dye was subjected to electrophoresis on a 1.5\% agarose gel. Electrophoresis was carried out for $40 \mathrm{~min}$ at $100 \mathrm{~V}$ in 1.5\% of agarose gel by using a submarine-type electrophoresis system (Mupid-ex, Advance, Tokyo, Japan). To visualize the DNA strand breaks, the gel was soaked in ethidium bromide solution for 5-10 min. Images of the agarose gel were taken under UV illumination using a ChemiDoc XRS (Bio-Rad, Hercules, CA, USA). To evaluate cell apoptosis, the fluorescence intensity of DNA in the gel was analyzed by a software named Quantity one. Apoptosis was 
expressed as the ratio of DNA to the DNA ladder. This experiment was conducted at least in triplicate.

\subsection{Determination of gene expression via RT-PCR}

Gene expression of caspase 9 was detected using the access RT-PCR kit and access RT-PCR introductory kit according to the manufacturers' instructions. Total RNA in PC12 cells treated with $5 \mu \mathrm{mol} / \mathrm{L} \mathrm{Cd}^{2+}$ and $0,2,5 \mu \mathrm{mol} / \mathrm{L} \mathrm{Zn}^{2+}$ for $48 \mathrm{~h}$ was extracted using SV total RNA isolation kit. The PCR primers for caspase 9 used were similar to those described by [29] Kawakami et al. (2008). The detailed sequences of the primers, expected sizes of PCR products, annealing temperatures, and cycles are summarized in Table 1. The PCR conditions were as follows: $48{ }^{\circ} \mathrm{C}$ for $45 \mathrm{~min}$ and $94{ }^{\circ} \mathrm{C}$ for $2 \mathrm{~min}$. The cycles were as follows: $94{ }^{\circ} \mathrm{C}$ for $30 \mathrm{~s}, 60{ }^{\circ} \mathrm{C}$ for $1 \mathrm{~min}$, and $68{ }^{\circ} \mathrm{C}$ for $2 \mathrm{~min}$. Final extension was carried out for $7 \mathrm{~min}$ at $68^{\circ} \mathrm{C}$. Forty cycles were performed, and an annealing temperature of $60{ }^{\circ} \mathrm{C}$ was used. $\beta$-Actin was selected as an internal control. PCR products were verified using a DNA 7500 assay with an Agilent 2100 Bio analyzer according to the manufacturer's instructions (Santa Clare, CA, USA). This experiment was carried out at least in triplicate.

\subsection{Western blot analysis for determination of protein expression}

Cytochrome c release in the cytosol was quantified using cytochrome c release apoptosis assay kit (Merk-Millipore, Darmstadt, Germany). PC12 cells were cultured in $5 \mathrm{~mL}$ of DMEM containing 10\% FBS, 0, $10 \mu \mathrm{mol} / \mathrm{L} \mathrm{Cd}^{2+}$, and 0, 10, 100, and $500 \mu \mathrm{mol} / \mathrm{L} \mathrm{Zn}^{2+}$. After 48-h treatment, the cells were harvested and centrifuged at 1,500 rpm for $5 \mathrm{~min}$ to remove the supernatant. After addition of $10 \mathrm{~mL}$ of ice-cold PBS, the mixture was centrifuged again at 1,500 rpm for $5 \mathrm{~min}$. After removal of the supernatants, the cells were resuspended in $150 \mu \mathrm{L}$ of cytosol extraction buffer mix (1× cytosol extraction buffer containing $1 \mathrm{~mL}$ of protease inhibitor cocktail and $2 \mathrm{mmol} / \mathrm{L} \mathrm{DTT}$ ). The mixture was allowed to stand on ice for $10 \mathrm{~min}$, and subsequently the cells were disrupted by sonication for 30 s using a Sonicator 250 (Branson). To remove the unbroken cells, the lysed cells were centrifuged at 3,000 rpm for $5 \mathrm{~min}$. The supernatant was transferred into a 1.5-mL tube and centrifuged at 11,000 rpm for $30 \mathrm{~min}$. The obtained final supernatant was collected as the cytosolic fraction for cytochrome c analysis. For determination of Bcl-2, Bax, and Bcl-x, $\beta$-actin lysis buffer (100 mmol/L HEPES, 1 mol/L NaCl, 
$300 \mathrm{mmol} / \mathrm{L}$ EGTA, $0.1 \mathrm{M}$ PMSF, $100 \mathrm{mmol} / \mathrm{L} \mathrm{Na}_{3} \mathrm{VO}_{4}, 10 \mathrm{mmol} / \mathrm{L} \mathrm{Na}_{2} \mathrm{MgO}_{4}, 100 \mathrm{mmol} / \mathrm{L} 2-$ glycerophosphoric acid, $1 \mathrm{mmol} / \mathrm{L} \mathrm{MgCl}_{2}, 100 \mathrm{mmol} / \mathrm{L} \mathrm{DTT}, 100 \mathrm{mmol} / \mathrm{L} \mathrm{NaF}$, and triton X100) was used to collect the protein fraction after two cycles of sonication followed by centrifugation at $1500 \mathrm{rpm}$ for $10 \mathrm{~min}$. After that, the protein concentration was determined spectrophotometrically by using protein assay dye reagent (Bio-Rad, Hercules, CA, USA). Then, the equal amount $(25 \mu \mathrm{g})$ of protein was separated via polyacrylamide gel electrophoresis (12.5$15 \%$ ), and the electrophoresed proteins were transferred to nitrocellulose membranes with a semidry blotting system, type-AE6678 (ATTO, Tokyo, Japan). The membranes were incubated overnight at $4{ }^{\circ} \mathrm{C}$ in $5 \%$ skimmed milk as a blocking agent. The membranes were incubated for $60 \mathrm{~min}$ at $37^{\circ} \mathrm{C}$ with the primary antibodies, washed three times, and then incubated with the secondary antibody for $60 \mathrm{~min}$. After washing for five times (each $3 \mathrm{~min}$ ), the protein bands were visualized using enhanced chemiluminescence. The images of the detected bands were analyzed using a ChemiDoc XRS (Bio-Rad, USA). Each experiment was conducted at least in triplicate to ensure reproducibility.

\subsection{Statistical analysis}

All data are expressed as the mean \pm standard error of mean (SEM). Statistical analyses were performed using single-factor analysis of variance (ANOVA) followed by unpaired Student's ttest.

\section{Table 1}

Primers used in RT-PCR analyses of caspases 9 and $\beta$-actin.

\begin{tabular}{|c|c|c|c|c|c|}
\hline $\begin{array}{l}\text { Primer's } \\
\text { name }\end{array}$ & Sequence $\left(5^{\prime} \rightarrow 3^{\prime}\right)$ & ng site (bp) & $\begin{array}{l}\text { Length } \\
\text { (bp) }\end{array}$ & $\begin{array}{l}\mathrm{T}_{\mathrm{m}} \\
\left({ }^{\circ} \mathrm{C}\right)\end{array}$ & $\begin{array}{l}\text { Cycle } \\
\text { (number) }\end{array}$ \\
\hline Bact F & ATGGATGACGATATCGCTG & & 19 & 61.1 & 40 \\
\hline Bact $\mathrm{R}$ & ATGAGGTAGTCTGTCAGGT & & 19 & 53.1 & 40 \\
\hline Casp 9F & CAAAGGAGCAGAAAGTAGTGAAG & 411-433 & 23 & 60.95 & 40 \\
\hline Casp 9R & GAGGAAGGGCAGAAGTTCAC & $687-668$ & 20 & 62.73 & 40 \\
\hline
\end{tabular}

\section{Results}

3.1. Cell viability 
To examine whether zinc $\left(\mathrm{Zn}^{2+}\right)$ affected cadmium $\left(\mathrm{Cd}^{2+}\right)$ toxicity, the viability of PC12 cells exposed to $0,10 \mu \mathrm{mol} / \mathrm{L} \mathrm{Cd}^{2+}$ and to 10,100 , and $500 \mu \mathrm{mol} / \mathrm{L} \mathrm{Zn}^{2+}$ for $48 \mathrm{~h}$ separately, as well as to a combination of both was measured via trypan blue staining (Fig. 1). The cell viability of PC12 cells was not reduced after treatment with $\mathrm{Zn}^{2+} 10 \mu \mathrm{mol} / \mathrm{L}$ and $100 \mu \mathrm{mol} / \mathrm{L}$ for $48 \mathrm{~h}$, but significantly decreased upon exposure to $\mathrm{Zn}^{2+} 500 \mu \mathrm{mol} / \mathrm{L}$ (Fig. S1). Cell viability significantly reduced after exposure to $\mathrm{Cd}^{2+}(10 \mu \mathrm{mol} / \mathrm{L})$, whereas it significantly increased after co-exposure to $\mathrm{Cd}^{2+}(10 \mu \mathrm{mol} / \mathrm{L})$ and $\mathrm{Zn}^{2+}(10,100 \mu \mathrm{mol} / \mathrm{L})$. However, it decreased upon exposure to $\mathrm{Cd}^{2+}$ $(10 \mu \mathrm{mol} / \mathrm{L})$ and $\mathrm{Zn}^{2+}$ (500 $\mu \mathrm{mol} / \mathrm{L}$ ) (Fig. 1). For comparison between the control, $\mathrm{Cd}^{2+}-\mathrm{Zn}^{2+}-$, and $\mathrm{Cd}^{2+}+\mathrm{Zn}^{2+}$ (1:1)-treatment groups, cell viability was also studied after 48-h exposure (data not shown). It was found that $\mathrm{Zn}^{2+}$ had no effect on cell viability $(<100 \mu \mathrm{mol} / \mathrm{L})$, whereas $\mathrm{Cd}^{2+}$ caused a significant decrease in cell viability $(2,5,10$, and $20 \mu \mathrm{mol} / \mathrm{L})$, and the $\mathrm{Cd}^{2+}+\mathrm{Zn}^{2+}$ treatment group showed significantly higher cell viability than the $\mathrm{Cd}^{2+}$-treatment group. The cell viability study confirmed that the combined exposure to $\mathrm{Cd}^{2+}$ and $\mathrm{Zn}^{2+}$ resulted in significantly higher cell viability than $\mathrm{Cd}^{2+}$ treatment only. On the basis of these results (Fig. 1), the treatment groups were decided as follows: control group (no treatment), $\mathrm{Cd}^{2+}$-treatment group $(10 \mu \mathrm{mol} / \mathrm{L}), \mathrm{Cd}^{2+}(10 \mu \mathrm{mol} / \mathrm{L})+\mathrm{Zn}^{2+}(10 \mu \mathrm{mol} / \mathrm{L})$-treatment group, $\mathrm{Cd}^{2+}(10 \mu \mathrm{mol} / \mathrm{L})+$ $\mathrm{Zn}^{2+}(100 \mu \mathrm{mol} / \mathrm{L})$-treatment group, $\mathrm{Cd}^{2+}(10 \mu \mathrm{mol} / \mathrm{L})+\mathrm{Zn}^{2+}(500 \mu \mathrm{mol} / \mathrm{L})$-treatment group.

\section{2. $\mathrm{LDH}$ activity after combined exposure to $\mathrm{Cd}^{2+}$ and $\mathrm{Zn}^{2+}$}

To investigate the combined effects of $\mathrm{Cd}^{2+}$ and $\mathrm{Zn}^{2+}$ on cytotoxicity, LDH activity assay was carried out in the culture medium of PC12 cells after treatment with/without $\mathrm{Cd}^{2+}(10 \mu \mathrm{mol} / \mathrm{L})$ and $\mathrm{Zn}^{2+}(10,100$, and $500 \mu \mathrm{mol} / \mathrm{L})$. The results showed that there was a significant difference between the treatment groups $(p<0.05)$. LDH activity significantly increased after treatment with $10 \mu \mathrm{mol} / \mathrm{L} \mathrm{Cd}^{2+}$ only (Fig. 2). However, after combined exposure to $10 \mu \mathrm{mol} / \mathrm{L} \mathrm{Cd}^{2+}$ along with 10 and $100 \mu \mathrm{mol} / \mathrm{L} \mathrm{Zn}^{2+}$, a reduction in LDH activity was observed, and increase in $\mathrm{Zn}^{2+}$ concentration to $500 \mu \mathrm{mol} / \mathrm{L}$ resulted in further increase in LDH activity. These results suggested that $\mathrm{Zn}^{2+}$ had protective effects against the cytotoxicity induced by $\mathrm{Cd}^{2+}(10 \mu \mathrm{mol} / \mathrm{L})$ in PC12 cells up to a certain concentration. Our findings are in agreement with the results of the cell viability study (Fig. 1). In addition, to confirm whether effects of $\mathrm{Zn}^{2+}$ on $\mathrm{Cd}^{2+}$ toxicity are observed in other cell line, we have done same experiments using HepG2 cell, a well- 
differentiated hepatocellular carcinoma cell. As shown in Fig. S2, $\mathrm{Zn}^{2+}$ has recovered $\mathrm{Cd}^{2+}$ toxicity in HepG2 cells as well as PC12 cells.

\subsection{Effects of simultaneous exposure of $\mathrm{Cd}^{2+}$ and $\mathrm{Zn}^{2+}$ on intracellular free SH levels}

Glutathione (GSH), a major thiol component of the cellular antioxidant system, has been shown to play an important role in protecting the cells against ROS, such as free radicals and peroxides [30]. GSH is usually oxidized to GSSG after stress stimuli, particularly oxidative stress. To examine the stress status in PC12 cells after combined exposure of $\mathrm{Cd}^{2+}$ and $\mathrm{Zn}^{2+}$, intracellular free SH levels were determined in cell lysates after treatment with/without $\mathrm{Cd}^{2+}$ and $\mathrm{Zn}^{2+}$ separately and in combinations. A significant reduction in free SH levels was observed after treatment with $\mathrm{Cd}^{2+}(10 \mu \mathrm{mol} / \mathrm{L})$ compared to the control group (Fig. 3). After combined exposure to $\mathrm{Cd}^{2+}(10 \mu \mathrm{mol} / \mathrm{L})$ and $\mathrm{Zn}^{2+}$ (10 or $100 \mu \mathrm{mol} / \mathrm{L}$ ), the levels of intracellular free SH increased significantly $(p<0.05)$ compared to the $\mathrm{Cd}^{2+}(10 \mu \mathrm{mol} / \mathrm{L})$-treatment group alone (Fig. 3). However, free $\mathrm{SH}$ level in the $\mathrm{Cd}^{2+}(10 \mu \mathrm{mol} / \mathrm{L})+\mathrm{Zn}^{2+}(500 \mu \mathrm{mol} / \mathrm{L})$-treatment group decreased to the same level as in the $\mathrm{Cd}^{2+}(10 \mu \mathrm{mol} / \mathrm{L})$ treatment group. These results indicated that $\mathrm{Zn}^{2+}$ (up to $100 \mu \mathrm{mol} / \mathrm{L}$ ) could reduce oxidative stress induced by $\mathrm{Cd}^{2+}$ in PC12 cells. This finding is also in accordance with the cell viability results (Fig. 1).

\subsection{DNA fragmentation analysis using agarose gel electrophoresis}

To clarify whether apoptosis was induced in PC12 cells treated with $\mathrm{Cd}^{2+}$, and to examine the effect of $\mathrm{Zn}^{2+}$ on $\mathrm{Cd}^{2+}$ toxicity, the genomic DNA extracted from PC12 cells treated with various concentrations of $\mathrm{Cd}^{2+}(0,2,5,10$, and $20 \mu \mathrm{mol} / \mathrm{L})$ and/or $\mathrm{Zn}^{2+}(0,2,5,10$, and $20 \mu \mathrm{mol} / \mathrm{L})$ for $48 \mathrm{~h}$ was electrophoresed using $1.5 \%$ agarose gel. The morphological characteristics of apoptosis are frequently accompanied by multiple cleavages of DNA resulting in fragments of 180-200 base pairs. The oligonucleosomal fragments can be visualized as a characteristic DNA ladder following agarose gel electrophoresis [31]. This DNA ladder pattern was observed for the cells treated with more than $5 \mu \mathrm{mol} / \mathrm{L} \mathrm{Cd}^{2+}$ (Fig. 4A). These results indicated that apoptosis was induced by $\mathrm{Cd}^{2+}$. In addition, DNA ladder pattern was significantly reduced upon addition of $\mathrm{Zn}^{2+}$ (1:1) in the medium containing $\mathrm{Cd}^{2+}$ (Fig. 4B), which confirmed the suppressive effects of $\mathrm{Zn}^{2+}$ on $\mathrm{Cd}^{2+}$-induced cytotoxicity and/or apoptosis. To evaluate the degree of apoptosis in the 
cell, the fluorescence intensity of DNA in the gels was analyzed. The relative intensity of DNA ladder after treatment with $\mathrm{Cd}^{2+}+\mathrm{Zn}^{2+}$ was higher than that after treatment with $\mathrm{Cd}^{2+}(0,2,5,10$, and $20 \mu \mathrm{mol} / \mathrm{L}$ ) only (Fig. 4C). These results indicated that apoptosis induced by $\mathrm{Cd}^{2+}(5,10$, and $20 \mu \mathrm{mol} / \mathrm{L})$ was suppressed by $\mathrm{Zn}^{2+}(2,5,10$, and $20 \mu \mathrm{mol} / \mathrm{L})$.

\subsection{Western blot analysis for determination of protein expression}

To examine whether $\mathrm{Zn}^{2+}$ could affect the proapoptotic environment induced by $\mathrm{Cd}^{2+}$ treatment, western blot analysis of the lysate of PC12 cells treated with $\mathrm{Cd}^{2+}(10 \mu \mathrm{mol} / \mathrm{L})$ or with $\mathrm{Cd}^{2+}(10 \mu \mathrm{mol} / \mathrm{L})+\mathrm{Zn}^{2+}(10,100$, and $500 \mu \mathrm{mol} / \mathrm{L})$ was performed to assess the protein expression of Bax, Bcl-2, Bcl-x, $\beta$-actin, and cytochrome $\mathrm{c}$. The western blot results are shown in Fig. 5(A-D). As shown in Fig. 5A, the proapoptotic Bax significantly increased after treatment with $10 \mu \mathrm{mol} / \mathrm{L} \mathrm{Cd}^{2+}$ compared to the control group. However, after combined exposure to $\mathrm{Cd}^{2+}$ $(10 \mu \mathrm{mol} / \mathrm{L})+\mathrm{Zn}^{2+}(10,100 \mu \mathrm{mol} / \mathrm{L})$, Bax protein expression was reduced, whereas it increased again after co-treatment with $\mathrm{Cd}^{2+}(10 \mu \mathrm{mol} / \mathrm{L})+\mathrm{Zn}^{2+}(500 \mu \mathrm{mol} / \mathrm{L})$. In addition, the levels of the antiapoptotic protein, Bcl-2 were relatively unchanged after both treatments (Fig. 5C); however, the levels of Bcl-x were found to be lower in the $\mathrm{Cd}^{2+}(10 \mu \mathrm{mol} / \mathrm{L})+\mathrm{Zn}^{2+}(10,100$ $\mu \mathrm{mol} / \mathrm{L})$-treatment group compared to the $\mathrm{Cd}^{2+}(10 \mu \mathrm{mol} / \mathrm{L})$-treatment group and $\mathrm{Cd}^{2+}(10$ $\mu \mathrm{mol} / \mathrm{L})+\mathrm{Zn}^{2+}(500 \mu \mathrm{mol} / \mathrm{L})$-treatment group. From these results, it was supposed that there was a net imbalance in Bax/Bcl-2 ratio, which indicated the occurrence of apoptosis in PC12 cells after treatment with $\mathrm{Cd}^{2+}$, whereas co-exposure to $\mathrm{Cd}^{2+}$ and $\mathrm{Zn}^{2+}$ resulted in reduction in proapoptotic Bax protein level. Consequently, the release of cytochrome c into the cytosol was also investigated (Fig. 5D). Results showed that the cells treated with $\mathrm{Cd}^{2+}(10 \mu \mathrm{mol} / \mathrm{L})$ only exhibited high content of cytochrome c, which was reduced after co-treatment with $\mathrm{Cd}^{2+}(10$ $\mu \mathrm{mol} / \mathrm{L})+\mathrm{Zn}^{2+}(10,100 \mu \mathrm{mol} / \mathrm{L})$; however, co-exposure to $\mathrm{Cd}^{2+}(10 \mu \mathrm{mol} / \mathrm{L})+\mathrm{Zn}^{2+}(500$ $\mu \mathrm{mol} / \mathrm{L}$ ) further increased cytochrome c levels. From these results, it was suggested that $\mathrm{Cd}^{2+}$ mainly induced the mitochondrial pathway of apoptosis, and $\mathrm{Zn}^{2+}$ suppressed $\mathrm{Cd}^{2+}$-induced cytochrome c release upon simultaneous exposure. To investigate the effects of the low exposure level, we examined the effects of co-exposure to $\mathrm{Cd}^{2+}(5 \mu \mathrm{mol} / \mathrm{L})+\mathrm{Zn}^{2+}(2,5,10$, and 20 $\mu \mathrm{mol} / \mathrm{L})$. We observed that $\mathrm{Zn}^{2+}$ (2, 5, 10, and $\left.20 \mu \mathrm{mol} / \mathrm{L}\right)$ suppressed cytochrome c release induced by $\mathrm{Cd}^{2+}(5 \mu \mathrm{mol} / \mathrm{L})$ (data not shown). Thus, it was confirmed that $\mathrm{Cd}^{2+}$ induced 
apoptosis in PC12 cells via activation of the mitochondrial pathway, whereas $\mathrm{Zn}^{2+}$ (10, 100 $\mu \mathrm{mol} / \mathrm{L})$ had a suppressive effect upon co-exposure with $\mathrm{Cd}^{2+}(5,10 \mu \mathrm{mol} / \mathrm{L})$.

\subsection{Expression of caspase 9}

To investigate the mechanism of apoptosis induced by $\mathrm{Cd}^{2+}$ and the effects of $\mathrm{Zn}^{2+}$ on the apoptotic pathways, changes in apoptotic factors of PC12 cells after treatment with $\mathrm{Cd}^{2+}$ and $\mathrm{Zn}^{2+}$ were determined using RT-PCR. The mRNA expression levels of caspase 9 in PC12 cells treated with $\mathrm{Cd}^{2+}(0,5 \mu \mathrm{mol} / \mathrm{L})$ and $\mathrm{Zn}^{2+}(2,5 \mu \mathrm{mol} / \mathrm{L})$ for $48 \mathrm{~h}$ are shown in Fig. 6. Caspase 9 mRNA levels were significantly $(p<0.05)$ higher in PC12 cells treated with $\mathrm{Cd}^{2+}(5 \mu \mathrm{mol} / \mathrm{L})$ compared to those in the control. Co-treatment with $\mathrm{Zn}^{2+}(2,5 \mu \mathrm{mol} / \mathrm{L})$ and $\mathrm{Cd}^{2+}(5 \mu \mathrm{mol} / \mathrm{L})$ resulted in the significant $(p<0.05)$ reduction in caspase 9 mRNA levels to the same level as that in the control cells.

\section{Discussion}

This study was conducted to test the hypothesis that co-exposure to the essential trace element, $\mathrm{Zn}^{2+}$, will antagonize the cytotoxicity and apoptosis induced by the toxic heavy metal $\mathrm{Cd}^{2+}$ in PC12 cells, a widely studied neuron model. The two metals were selected because of their similar chemical characteristics and the high possibility of co-exposure. The present study showed that $\mathrm{Cd}^{2+}(5 \mu \mathrm{mol} / \mathrm{L})$ induced apoptosis in PC12 cells. Similar results have been observed in previous studies using HeLa cells and BAECs [16]. $\mathrm{Cd}^{2+}$-induced DNA fragmentation and formation of apoptotic bodies have been observed by several investigators under different experimental conditions, including $\mathrm{Cd}^{2+}$-induced apoptosis in the testis of freshwater crab [32] and in pancreatic $\beta$-cells [33]. Our results also showed DNA fragmentation in PC12 cells exposed to $\mathrm{Cd}^{2+}$ (Fig. 4). Various mechanisms could be involved in $\mathrm{Cd}^{2+}$-induced DNA damage, including activation of $\mathrm{Ca}^{2+}$-dependent endonucleases resulting in DNA fragmentation and interference with the DNA repair process [13, 15, 34, 35]. In addition, $\mathrm{Cd}^{2+}$ toxicity could be partly due to oxidative stress induced by ROS produced in the cells in response to metal ions [36, 37]. $\mathrm{Cd}^{2+}$ induces the expression of hemeoxygenase enzyme, which generates ROS, in various cell types [38, 39]. Some evidence suggests that $\mathrm{Cd}^{2+}$-MT complexes can induce ROS, which in turn cause DNA damage in cells [40]. Intracellular levels of free SH groups determined in this study confirmed that $\mathrm{Cd}^{2+}(10 \mu \mathrm{mol} / \mathrm{L})$ exposure induces oxidative stress, and that co-exposure to $\mathrm{Zn}^{2+}$ (10 or $100 \mu \mathrm{mol} / \mathrm{L}$ ) prevented this effect (Fig. 3). In our study, co- 
exposure to $\mathrm{Zn}^{2+}$ (10 or $100 \mu \mathrm{mol} / \mathrm{L}$ ) significantly increased the level of GSH relative to that found in cells treated with $\mathrm{Cd}^{2+}$ only. A further increase in $\mathrm{Zn}^{2+}$ concentration (to $500 \mu \mathrm{mol} / \mathrm{L}$ ) reduced the level of GSH. These results indicate that $\mathrm{Cd}^{2+}$-induced oxidative stress decreases in the presence of $\mathrm{Zn}^{2+}$ in PC12 cells, which confirms the antioxidant effects of $\mathrm{Zn}^{2+}$ in cells exposed to $\mathrm{Cd}^{2+}$. The reduction of $\mathrm{Cd}^{2+}$-induced oxidative stress by $\mathrm{Zn}^{2+}$ may also be due to the combined influence of both metal ions as described in a previous study [22]. Supplementation with $\mathrm{Zn}^{2+}$ may also diminish the inhibitory potency of $\mathrm{Cd}^{2+}$ on the antioxidant enzymes SOD, peroxidase, and catalase [20, 40]. Furthermore, LDH activity in cell culture medium significantly increased after treatment with $\mathrm{Cd}^{2+}(10 \mu \mathrm{mol} / \mathrm{L})$. Simultaneous exposure to $\mathrm{Zn}^{2+}$ (10 or 100 $\mu \mathrm{mol} / \mathrm{L})$ and $\mathrm{Cd}^{2+}(10 \mu \mathrm{mol} / \mathrm{L})$ markedly inhibited leakage of LDH into the culture medium of PC12 cells (Fig. 2). Again, increasing the concentration of $\mathrm{Zn}^{2+}$ to $500 \mu \mathrm{mol} / \mathrm{L}$ increased the leakage of $\mathrm{LDH}$ into the culture medium. These findings suggest that $\mathrm{Zn}^{2+}$ might act as a scavenger of $\mathrm{ROS}$ produced by $\mathrm{Cd}^{2+}$; alternatively, $\mathrm{Zn}^{2+}$ could compete with $\mathrm{Cd}^{2+}$ for accumulation sites in PC12 cells. The viability of PC12 cells exposed to $\mathrm{Cd}^{2+}$ decreases in a concentration-dependent manner (data not shown). However, when cells are co-exposed to $\mathrm{Zn}^{2+}$ (10 or $100 \mu \mathrm{mol} / \mathrm{L}$ ), their viability significantly increases (Fig. 1). A further increase in $\mathrm{Zn}^{2+}$ concentration (to $500 \mu \mathrm{mol} / \mathrm{L}$ ) synergistically promoted $\mathrm{Cd}^{2+}(10 \mu \mathrm{mol} / \mathrm{L}$ )-induced apoptosis. Similarly, DNA fragmentation caused by $\mathrm{Cd}^{2+}$ was suppressed by addition of $\mathrm{Zn}^{2+}$ (Fig. 4). These results suggest that apoptosis induced by $\mathrm{Cd}^{2+}$ in PC12 cells is inhibited by the addition of $\mathrm{Zn}^{2+}$ up to $100 \mu \mathrm{mol} / \mathrm{L}$. This finding agrees with the results of previous studies, which showed that addition of $\mathrm{Zn}^{2+}$ significantly inhibits $\mathrm{Cd}^{2+}$-induced apoptosis in HeLa cells and reduces ROS production in BAECs [16]. Previous studies have also shown that $\mathrm{Zn}^{2+}$ ions can inhibit DNA fragmentation and apoptosis induced by other stimuli in multiple in vivo and in vitro biological systems [16, 22, 24].

To clarify the mechanism by which $\mathrm{Zn}^{2+}$ suppresses $\mathrm{Cd}^{2+}$-induced apoptosis, western blot (Fig. 5A-D) and RT-PCR (Fig. 6) analyses were carried out. The results indicated that $\mathrm{Cd}^{2+}(10$ $\mu \mathrm{mol} / \mathrm{L}$ )-mediated increased expression of caspase 9 and mitochondrial release of cytochrome $\mathrm{c}$ were suppressed by addition of $\mathrm{Zn}^{2+}$ (2, 5, 10 or $\left.100 \mu \mathrm{mol} / \mathrm{L}\right)$. Apoptosis can be triggered by the activation of death receptors (extrinsic pathway) or induction of mitochondria-mediated signaling pathways (intrinsic pathway). The intrinsic apoptotic pathway is regulated by members of the Bcl-2 protein family, which also play a central role in regulating mitochondrial membrane 
permeability [41, 42]. Cytochrome c is a key regulator of the intrinsic pathway, activating caspase-dependent apoptosis. Release of cytochrome c from the mitochondria to the cytosol depends on certain factors, including mitochondrial membrane potential (MMP) and membrane integrity. The proapoptotic Bcl-2 family member Bax can interact with the mitochondrial permeability transition (MPT) pore components, particularly the voltage-dependent anion channel (VDAC), to release cytochrome c into the cytosol. In addition, it can alter the MMP and initiate swelling of mitochondrial organelles. Under conditions of cellular homeostasis, cytochrome c binds to the inner mitochondrial membrane in association with the anionic phospholipid, cardiolipin. Studies have suggested that dissociation of cardiolipin from cytochrome c could be the critical step in its release into the cytosol [43, 44]. Several studies have shown that changes in levels or chemical structure of cardiolipin can create a soluble pool of cytochrome c within the mitochondrial intermembrane space, which can promote release of cytochrome c into the cytosol upon permeabilization of the outer mitochondrial membrane [45, 46]. In our study, the increased level of cytochrome $c$ in the cytosol upon $\mathrm{Cd}^{2+}(10 \mu \mathrm{mol} / \mathrm{L})$ exposure suggests that $\mathrm{Cd}^{2+}$ influences MMP in PC12 cells. The release of cytochrome c from mitochondria into the cytosol accelerates activation of caspase 9, initiating a downstream caspase cascade, ultimately leading to cell death [15, 26]. In this study cytosolic levels of the proapoptotic proteins Bax and cytochrome c increased upon $\mathrm{Cd}^{2+}(10 \mu \mathrm{mol} / \mathrm{L})$ exposure, and cotreatment with $\mathrm{Zn}^{2+}$ (10 or $100 \mu \mathrm{mol} / \mathrm{L}$ ) significantly suppressed these increases. A further increase in $\mathrm{Zn}^{2+}$ concentration to $500 \mu \mathrm{mol} / \mathrm{L}$ has an opposite effect in $\mathrm{Cd}^{2+}(10 \mu \mathrm{mol} / \mathrm{L})$-treated cells. One explanation is that co-treatment with $\mathrm{Zn}^{2+}$ might ameliorate $\mathrm{Cd}^{2+}$-induced production of excess ROS in PC12 cells. Previous studies reported similar effects in $\mathrm{Zn}^{2+}$ on $\mathrm{Cd}^{2+}$ exposure in different cell lines [16, 23, 24].

In the present study, we showed the suppressive effects of $\mathrm{Zn}^{2+}$ on $\mathrm{Cd}^{2+}$-induced apoptosis in PC12 cells for the first time. $\mathrm{Zn}^{2+}$ is a redox-inactive metal, which is considered to be an important part of the cellular antioxidant system. The ability of $\mathrm{Zn}^{2+}$ to maintain cellular redox balance can be attributed to several possible molecular mechanisms, including regulation of oxidant production, induction of oxidative damage [23], induction of the $\mathrm{Zn}^{2+}$-binding protein, MT [24], involvement in regulation of GSH metabolism [47], and direct or indirect regulation of redox signaling [20]. The normal cellular amount of $\mathrm{Zn}^{2+}$ is very small, and most of it strongly binds to proteins and other molecules, including GSH. One study showed that 5-10 pmol of $\mathrm{Zn}^{2+}$ 
is present in the cytosol and nucleus of resting PC12 cells [15]. $\mathrm{Zn}^{2+}$ can modulate cellular oxidant production, and bind to SH groups to protect them from oxidation. In our present study, $\mathrm{Cd}^{2+}(10 \mu \mathrm{mol} / \mathrm{L})$ induced oxidative stress, leading to the cell death and this may be due to displacement of $\mathrm{Zn}^{2+}$ bound to thiol groups (Figs. 1 and 2) . Co-treatment with $\mathrm{Zn}^{2+}$ (10 or 100 $\mu \mathrm{mol} / \mathrm{L}$ ) suppressed cell death and LDH activity relative to that in cells treated with $\mathrm{Cd}^{2+}$ only, possibly due to the increased supply of $\mathrm{Zn}^{2+} \cdot \mathrm{Zn}^{2+}$ may also modulate oxidant levels by binding to SH groups of thiols. In addition, it may enhance/initiate synthesis of metal binding proteins such as MT. In neural cells, $\mathrm{Cd}^{2+}$ exposure is reported to significantly decreases $\mathrm{Zn}^{2+}$ content in proteins, hinder the enzymatic activity of $\mathrm{Cu} / \mathrm{Zn}-\mathrm{SOD}$, and induce significant conformational changes in proteins that ultimately lead to neural cell apoptosis [48]. In this study, we observed a significant increase in levels of GSH in co-treated cells $\left(\mathrm{Cd}^{2+} 10 \mu \mathrm{mol} / \mathrm{L}+\mathrm{Zn}^{2+} 10\right.$ or 100 $\mu \mathrm{mol} / \mathrm{L})$ compared to that in $\mathrm{Cd}^{2+}(10 \mu \mathrm{mol} / \mathrm{L})$-treated cells. Therefore, $\mathrm{Zn}^{2+}(10$ or $100 \mu \mathrm{mol})$ supplementation effectively protects PC12 cells against $\mathrm{Cd}^{2+}(10 \mu \mathrm{mol} / \mathrm{L})$-induced oxidative stress, possibly through modulation of intracellular GSH levels. Moreover, $\mathrm{Cd}^{2+}$ can induce MT synthesis, resulting in the formation of intracellular $\mathrm{Cd}^{2+}$-MT complexes, which can cause apoptosis. Similar to $\mathrm{Cd}^{2+}, \mathrm{Zn}^{2+}$ exposure can also initiate synthesis of MT. Although we did not investigate the involvement of metal-binding proteins/chaperones, this possibility cannot be neglected. It can be speculated from our study that co-treatment of PC12 cells with $\mathrm{Cd}^{2+}$ and $\mathrm{Zn}^{2+}$ can affect the formation and chemistry of MT. Additional studies are needed to evaluate this hypothesis. Suzuki et al. [49] showed that co-treatment with $\mathrm{Cd}^{2+}$ and $\mathrm{Zn}^{2+}$ salts might increase synthesis of MT in different organs, including the liver, kidneys, and pancreas, relative to that reported for treatment with $\mathrm{Cd}^{2+}$ or $\mathrm{Zn}^{2+}$ alone. When cells are exposed to $\mathrm{Cd}^{2+}$ and $\mathrm{Zn}^{2+}$ simultaneously, both metals compete for MT binding sites [7]. We measured caspase mRNA levels after exposure to $\mathrm{Cd}^{2+}$, or $\mathrm{Cd}^{2+}$ and $\mathrm{Zn}^{2+}$. Caspase 9 mRNA levels significantly $(p<0.05)$ increased after treatment with $\mathrm{Cd}^{2+}(5 \mu \mathrm{mol} / \mathrm{L})$; however, the levels decreased significantly $(p<0.05)$ upon co-treatment of $\mathrm{Cd}^{2+}$-treated cells with $\mathrm{Zn}^{2+}$ (2 or $\left.5 \mu \mathrm{mol} / \mathrm{L}\right)$. Thus, $\mathrm{Zn}^{2+}$ effectively inhibited $\mathrm{Cd}^{2+}$-induced expression of caspase 9 , possibly explaining its mechanism of inhibiting $\mathrm{Cd}^{2+}$-induced apoptosis in PC12 cells. Previous studies have shown similar results, suggesting that $\mathrm{Zn}^{2+}$ can inhibit maturation of caspase 3, an apoptotic protease, which acts upstream of the endonuclease in apoptotic cell death [22, 50]. In addition, Kumari et al. (2011) [51] showed that prepubertal dietary $\mathrm{Zn}^{2+}$ deficiency induced apoptotic changes in the testes of 
Wistar rats. Our results indicate that $\mathrm{Cd}^{2+}$ induces apoptosis via the mitochondrial pathway, and $\mathrm{Zn}^{2+}$ supplementation inhibits this induced cell death process. It has also been reported that $\mathrm{Zn}^{2+}$ can inhibit activation of caspase 9 in different cells [22, 23, 52]. Additionally, it is known that $\mathrm{Zn}^{2+}$ reduces $\mathrm{Cd}^{2+}$ accumulation in biological systems both in vivo and in vitro [15 24]. Low concentrations of $\mathrm{Zn}^{2+}$ may inhibit activation of caspase 9, while high concentrations inhibit accumulation of $\mathrm{Cd}^{2+}$ in cells. Therefore, our findings confirm the antioxidative effects of $\mathrm{Zn}^{2+}$ against $\mathrm{Cd}^{2+}$-induced oxidative stress and its inhibitory effects against $\mathrm{Cd}^{2+}$-induced apoptosis in PC12 cells.

\section{Conclusion}

Our present findings indicate that Zn co-treatment protected PC12 cells against Cd induced oxidative stress, loss of cell membrane integrity, DNA fragmentation, and ultimately, apoptotic cell death via the mitochondrial pathway. In addition, $\mathrm{Zn}^{2+}$ and $\mathrm{Cd}^{2+}$ may cooperatively induce synthesis of metal binding proteins/chaperones to neutralize the possible adverse effects of $\mathrm{Cd}^{2+}$ in neuron-like PC12 cells.

\section{Acknowledgments}

The authors give special thanks to Ms. Miyako Komori, for her kind cooperation during experiments and express heartiest gratitude to all laboratory members for their constant support during manuscript preparation.

\section{References}

[1] M.T. Rafiq, R. Aziz, X. Yang, W. Xiao, M.K. Rafiq, B. Ali, T. Li, Cadmium phytoavailability to rice (Oryza sativa L.) grown in representative Chinese soils. A model to improve soil environmental quality guidelines for food safety, Ecotoxicol. Environ. Saf. 103 (2014) 101-107.

[2] A. Rani, A. Kumar, A. Lal, M. Pant, Cellular mechanisms of cadmium-induced toxicity: a review, Int. J. Environ. Health Res. 24 (2014) 378-399.

[3] S. Satarug, M.R. Moore, Adverse health effects of chronic exposure to low-level cadmium in foodstuffs and cigarette smoke, Environ. Health Perspect. 112 (2004) 1099-1103. 
[4] D. Beyersmann, S. Hechtenberg, Cadmium, gene regulation and cellular signaling in mammalian cells, Toxicol. Appl. Pharmacol. 144 (1997) 247-261.

[5] D. Beyersmann, A. Hartwig, Carcinogenic metal compounds: recent insight into molecular and cellular mechanisms, Arch. Toxicol. 82 (2008) 493-512. DOI 10.1007/s00204-0080313-y

[6] E.R. Siu, D.D. Mruk, C.S. Porto, C.Y. Cheng, Cadmium-induced testicular injury, Toxicol. Appl. Pharmacol. 238 (2009) 240-249.

[7] I. Sabolić, D. Breljak, M. Škarica, C.M. Herak-Kramberger, Role of metallothionein in cadmium traffic and toxicity in kidneys and other mammalian organs, Biometals 23 (2010) 897-926.

[8] S. Bar-sela, S. Reingold, E.D. Richter, Amyotrophic lateral sclerosis in a battery- factory worker exposed to cadmium, Int. J. Occup. Environ. Health 7 (2001) 109-112.

[9] L.C. Baxter, D.L. Sparks, S.C. Johnson, B. Lenoski, J.E. Lopez, D.J. Connor, M.N. Sabbagh, Relationship of cognitive measures and gray and white matter in Alzheimer's disease, J. Alzheimers Dis. 9 (2006) 253-260.

[10] S. Kim, C. Moon, S. Eun, P. Ryu, S. Jo, Identification of ASK1, MKK4, JNK, c-Jun, and caspase-3 as a signaling cascade involved in cadmium-induced neuronal cell apoptosis, Biochem. Biophys. Res. Commun. 328 (2005) 326-334.

[11] E. Lopez, C. Arce, M.J. Oset-Gasque, S. Canadas, M.P. Gonzalez, Cadmium induces reactive oxygen species generation and lipid peroxidation in cortical neurons in culture, Free Radic. Biol. Med. 40 (2006) 940-951. doi:10.1016/j.freeradbiomed.2005.10.062

[12] A. Shukla, G.S. Shukla, R.C. Srimal, Cadmium-induced alterations in blood-brain barrier permeability and its possible correlation with decreased microvessel antioxidant potential in rat, Hum. Exp. Toxicol. 15 (1996) 400-405.

[13] M. Li, T. Xia, C.S. Jiang, L.J. Li, J.L. Fu, Z.C. Zhou, Cadmium directly induced the opening of membrane permeability pore of mitochondria which possibly involved in cadmium triggered apoptosis, Toxicology 194 (2003) 19-33.

[14] C. Long, L. Lei, H. Shile, Cadmium activates the mitogen-activated protein kinase (MAPK) pathway via induction of reactive oxygen species and inhibition of protein phosphatases $2 \mathrm{~A}$ and 5, Free Radic. Biol. Med. 45 (2008) 1035-1044. 
[15] C. Jiang, Y. Yuan, F. Hu, Q. Wang, K. Zhang, Y. Wang, J. Gu, G. Liu, J. Bian, Z. Liu, Cadmium induces PC12 cells apoptosis via an extracellular signal-related kinase and c-jun N-terminal kinase-mediated mitochondrial apoptotic pathway, Biol. Trace Elem. Res. 158 (2014) 249-258.

[16] A. Szuster-Ciesielska, A. Stachura, M. Slotwinska, T. Kaminska, R. Sniezko, R. Paduch, D. Abramczyk, J. Zef Filar, M. Kandefer-Szerszen, The inhibitory effect of zinc on cadmiuminduced cell apoptosis and reactive oxygen species (ROS) production in cell cultures. Toxicology 145 (2000) 159-171.

[17] D.M. Templeton, Y. Liu, Multiple roles of cadmium in cell death and survival, Chem. Biol. Interact. 188 (2010) 267-275.

[18] J.Y. Uriu-Adams, C.L. Keen, Zinc and reproduction: effects of zinc deficiency on prenatal and early postnatal development, Birth Defects Res. B Dev. Reprod. Toxicol. 89 (2010) 313-325.

[19] C. Andreini, I. Bertini, A bioinformatics view of zinc enzymes, J. Inorg. Biochem. 111 (2012) 150-156.

[20] P.I. Oteiza, Zinc and the modulation of redox homeostasis, Free Radic. Biol. Med. 53(9) (2012) 1748-1759. doi:10.1016/j.freeradbiomed.2012.08.568

[21] D. Barbieri, L. Troiano, E. Grassilli, C. Agnesini, E.A. Cristofalo, D. Monti, M. Capri, A. Cossarizza, C. Franceschi, Inhibition of apoptosis by zinc: a reappraisal, Biochem. Biophys. Res. Commun. 187 (1992) 1256-1261.

[22] M.M. Brzóska, M. Galażyn-Sidorczuk, J. Rogalska, A. Roszczenko, M. Jurczuk, K. Majewska, J. Moniuszko-Jakoniuk, Beneficial effect of zinc supplementation on biomechanical properties of femoral distal end and femoral diaphysis of male rats chronically exposed to cadmium, Chem. Biol. Interact. 171 (2008) 312-324.

[23] J. Rogalska, M.M. Brzóska, A. Roszczenko, J. Moniuszko-Jakoniuk, Enhanced zinc consumption prevents cadmium-induced alterations in lipid metabolism in male rats, Chem. Biol. Interact. 177 (2009) 142-152. 
[24] J. Rogalska, B. Pilat-Marcinkiewicz, M.M. Brzóska, Protective effect of zinc against cadmium hepatotoxicity depends on this bioelement intake and level of cadmium exposure: A study in a rat model, Chem. Biol. Interact. 193 (2011) 191-203.

[25] A. Formigari, P. Irato, A. Santon, Zinc, antioxidant systems and metallothionein in metal mediated-apoptosis: biochemical and cytochemical aspects, Comp. Biochem. Physiol. C 146 (2007) 443-459.

[26] L. Aimo, G.N. Cherr, P.I. Oteiza, Low extracellular zinc increases neuronal oxidant production through nadph oxidase and nitric oxide synthase activation, Free Radic. Biol. Med. 48 (2010) 1577-1587.

[27] W. Maret, Redox biochemistry of mammalian metallothioneins, J. Biol. Inorg. Chem. 16 (2011) 1079- 1086.

[28] Y. Kihara, Yustiawati, M. Tanaka, S. Gumiri, Ardianor, T. Hosokawa, S. Tanaka, T. Saito, M. Kurasaki, Mechanism of the toxicity induced by natural humic acid on human vascular endothelial cells, Environ. Toxicol. 29(8) (2012) 916-925. DOI 10.1002/tox.21819

[29] M. Kawakami, R. Inagawa, T. Hosokawa, T. Saito, M. Kurasaki, Mechanism of apoptosis induced by copper in PC12 cells, Food Chem. Toxicol. 46 (2008) 2157-2164.

[30] P. Alfonso, V. Athanase, P. Aldo, D.T. Vincenzo, F.C. Alessandro, The changing faces of glutathione, a cellular protagonist, Biochem. Pharmacol. 66 (2003) 1499-1503.

[31] A. Woodgate, G. MacGibbon, M. Walton, M. Dragunow, The toxicity of 6hydroxydopamine on PC12 and P19 cells, Brain Res. Mol. Brain Res. 69 (1999) 84-92.

[32] L. Wang, T. Xu, W.W. Lei, D.M. Liu, Y.J. Li, R.J. Xuan, J.J. Ma, Cadmium-induced oxidative stress and apoptotic changes in the testis of freshwater Crab, Sinopotamon henanense, PLoS ONE 6(11) (2011) e27853. doi:10.1371/journal.pone.0027853

[33] K.C. Chang, C.C. Hsu, S.H. Liu, C.C. Su, C.C. Yen, M.J. Lee, K.L. Chen, T.J. Ho, D.Z. Hung, C.C. Wu, T.H. Lu, Y.C. Su, Y.W. Chen, C.F. Huang, Cadmium induces apoptosis in pancreatic $\beta$-cells through a mitochondria-dependent pathway: The role of oxidative stressmediated c-Jun N-terminal kinase activation, PLoS ONE 8(2) (2013) e54374. doi:10.1371/journal.pone.0054374

[34] Y. Yuan, C.Y. Jiang, H. Xu, Y. Sun, F.F. Hu, J.C. Bian, X.Z. Liu, J.H. Gu, Z.P. Liu, Cadmium-Induced Apoptosis in Primary Rat Cerebral Cortical Neurons Culture Is Mediated 
by a Calcium Signaling Pathway, PLoS ONE 8(5) (2013) e64330. doi:10.1371/journal.pone.0064330

[35] R.D. Lohman, D. Beyersmann, Cadmium and zinc mediated changes of the Ca2-dependent endonuclease in apoptosis, Biochem. Biophys. Res. Commun. 190 (1993) 1097-1103.

[36] E.A. Hassoun, S.J. Stohs, Cadmium-induced production of superoxide anion and nitric oxide, DNA single strand breaks and lactate dehydrogenase leakage in J774A.1 cell cultures, Toxicology 112 (1996) 219-226.

[37] G. Fotakis, J.A. Timbrell, In-vitro cytotoxicity assay: comparison of LDH, Neutral red, MTT and protein assay in hepatoma cell lines following exposure to cadmium chloride. Toxicol. Lett. 160 (2006) 171-177.

[38] J.O. Ossola, M.L. Tomoro, Heme oxygenase induction by cadmium chloride: evidence for oxidative stress involvement, Toxicology 104 (1995) 141-147.

[39] K. Srisook, N.H. Jung, B.R. Kim, S.H. Cha, H.S. Kim, Y.N. Cha, Heme oxygenase-1 mediated partial cytoprotective effect by $\mathrm{NO}$ on cadmium induced cytotoxicity in C6 rat glioma cells, Toxicol. In Vitro 19 (2005) 31-39.

[40] T. Muller, R. Schuckelt, L. Jaenicke, Evidence for radical species as intermediates in cadmium:zinc-metallothionein- dependent DNA damage in vitro, Environ. Health Perspect. 102 (1994) 27-29.

[41] J.M. Adams, S. Cory, Life-or-death decisions by the Bcl-2 protein family, Trends Biochem. Sci. 26 (2001) 61-66.

[42] J.E. Chipuk, D.R. Green, How do BCL-2 proteins induce mitochondrial outer membrane permeabilization? Trends Cell Biol. 18 (2008) 157-164.

[43] V. Gogvadze, S. Orrenius, Mitochondrial regulation of apoptotic cell death. Chem. Biol. Interact. 163 (2006) 4-14.

[44] E.K.J. Tuominen, C.J.A. Wallace, P.K.J. Kinnunen, Phospholipid-Cytochrome $c$ interaction: evidence for the extended lipid anchorage, J. Biol. Chem. 277 (2002) 8822-8826.

[45] G. Petrosillo, F.M. Ruggiero, M. Pistolese, G. Paradies, Reactive oxygen species generated from the mitochondrial electron transport chain induce Cytochrome $c$ dissociation from beef-heart submitochondrial particles via cardiolipin peroxidation; Possible role in the apoptosis, FEBS Lett. 509 (2001) 435-438. 
[46] M. Ott, J.D. Robertson, V. Gogvadze, B. Zhivotovsky, S. Orrenius, Cytochrome $c$ release from mitochondria proceeds by a two-step process, Proc. Natl. Acad. Sci. USA. 99 (2002) 1259-1263.

[47] G.G. Mackenzie, G.A. Salvador, C. Romero, C.L. Keen, P.I. Oteiza, A deficit in zinc availability can cause alterations in tubulin thiol redox status in cultured neurons and in the developing fetal rat brain. Free Radic. Biol. Med. 51 (2011) 480-489.

[48] YH, Huang, C.M. Shih, C.J. Huang, C.M. Lin, C.M. Chou, M.L. Tsai, T.P. Liu, J.F. Chiu, C.T. Chen, Effects of cadmium on structure and enzymatic activity of $\mathrm{Cu}, \mathrm{Zn}-\mathrm{SOD}$ and oxidative status in neural cells. J. Cell. Biochem. 98 (2006) 577-589.

[49] C.A. Suzuki, H. Ohta, A. Albores, J. Koropatnic, M.G. Cherian, Induction of mettalothionein synthesis by zinc in cadmium pretreated rats, Toxicology 63 (1990) 273-284

[50] T. Aiuchi, S. Mihara, M. Nakaya, Y. Masuda, S. Nakajo, K. Nakaya, Zinc ions prevent processing of caspase-3 during apoptosis induced by geranylgeraniol in HL-60 cells, J. Biochem. 124 (1998) 300- 303.

[51] D. Kumari, N. Nair, R.S. Bedwal, Testicular apoptosis after dietary zinc deficiency: ultrastructual and TUNEL studies, Syst. Biol. Reprod. Med. 57 (2011) 233-243.

[52] A. Formigari, E. Gregianin, P. Irato, The effect of zinc and the role of p53 in copperinduced cellular stress responses, J. Appl. Toxicol. 33 (2013) 527-536. 


\section{Figure legends}

Fig. 1. Viability of PC12 cells with and without $\mathrm{Cd}^{2+} / \mathrm{Cd}^{2+}+\mathrm{Zn}^{2+}$ treatment at different concentrations after 48-h incubation measured via trypan blue staining method. Each experiment was conducted five times independently to ensure biological reproducibility. Cells co-exposed to $10 \mu \mathrm{mol} / \mathrm{L} \mathrm{Cd}^{2+}$ and $10-500 \mu \mathrm{mol} / \mathrm{L} \mathrm{Zn}^{2+}$. Error bars indicate the mean $\pm \operatorname{SEM}(n=5)$, * denotes significance at $p<0.05$ compared to control. There is also a significant difference $(p<0.05)$ between $a$ and $b$.

Fig. 2. LDH activity in the culture medium of PC12 cells with and without $\mathrm{Cd}^{2+} / \mathrm{Cd}^{2+}+\mathrm{Zn}^{2+}$ treatment at different concentrations after $48 \mathrm{~h}$ measured by non-radiative cytotoxicity assay kit. Each experiment was conducted three times for reproducibility. Error bars indicate mean \pm SEM $(n=3)$. Error bars indicate the mean $\pm \operatorname{SEM}(n=3)$, * denotes significance at $p<0.05$ compared to control. There is also a significant difference $(\mathrm{p}<0.05)$ between a and $\mathrm{b}$.

Fig. 3. Intracellular free-SH levels in PC12 PC12 cells with and without $\mathrm{Cd}^{2+} / \mathrm{Cd}^{2+}+\mathrm{Zn}^{2+}$ treatment at different concentrations after $48 \mathrm{~h}$ determined via DTNB assay method. Each experiment was carried out three times independently for ensuring reproducibility. Error bars indicate the mean \pm SEM $(n=3)$, * denotes significance at $\mathrm{p}<0.05$ compared to control. There is also a significant difference $(\mathrm{p}<0.05)$ between $\mathrm{a}$ and $\mathrm{b}$.

Fig. 4. Agarose gel electrophoresis of genomic DNA extracted from PC12 cells cultured in the medium with and without $\mathrm{Cd}^{2+} / \mathrm{Cd}^{2+}+\mathrm{Zn}^{2+}$ for $48 \mathrm{~h}$. It was conducted four times to confirm biological reproducibility. A) DNA from the cells treated with 0-20 $\mu \mathrm{mol} / \mathrm{L} \mathrm{Cd}^{2+}$, B) DNA from the cells treated with $0-20 \mu \mathrm{mol} / \mathrm{L} \mathrm{Cd}^{2+}$ and $0-20 \mu \mathrm{mol} / \mathrm{L} \mathrm{Zn}^{2+}, \mathrm{C}$ ) the fluorescent intensity of genomic DNA extracted from PC12 cells cultured in the medium for $48 \mathrm{~h}$ after treatment with 0 $20 \mu \mathrm{mol} / \mathrm{L} \mathrm{Cd}^{2+}$ and $0-20 \mu \mathrm{mol} / \mathrm{L} \mathrm{Zn}^{2+}$. Lane $\mathrm{M}$ in the Figs. A and B means $\lambda$ DNA digested with HindIII for the marker. The values are calculated following formula; (DNA/ DNA and DNA ladder $) \times 100$. Error bars indicate mean \pm S.E.M. $(n=4)$. Significant difference between a and $\mathrm{b}$ is observed $(\mathrm{P}<0.05)$.

Fig. 5. Western blot analyses for the relative contents of A; Bax, B; Bcl2, C; Bclx and D; cytochrome c $48 \mathrm{~h}$ after treatment with and without $\mathrm{Cd}^{2+} / \mathrm{Cd}^{2+}+\mathrm{Zn}^{2+}$ treatment. Each experiment was conducted three times separately to ensure reproducibility. Immunostaining bands are present above the bar diagram for respective protein. M means Error bars indicate the mean \pm SEM $(n=3)$, * denotes significance at $p<0.05$ compared to control. There is also a significant difference $(p<0.05)$ between a and b.

Fig. 6. Expression levels of caspase 9 mRNA in PC12 cells cultured in the medium containing 5 $\mu \mathrm{mol} / \mathrm{L} \mathrm{Cd}^{2+}$ and $0-5 \mu \mathrm{mol} / \mathrm{L} \mathrm{Zn}^{2+}$ for $48 \mathrm{~h}$ using of RT-PCR method. Expression level of caspase 9 mRNA is expressed as $\mathrm{nmol} / \mathrm{nmol}$ of $\beta$-actin which used as an internal control. Error bars indicate the mean $\pm \operatorname{SEM}(n=4)$, * denotes significance at $p<0.05$ compared to control. There is also a significant difference $(p<0.05)$ between a and $b$. 
A $\quad 12 C$

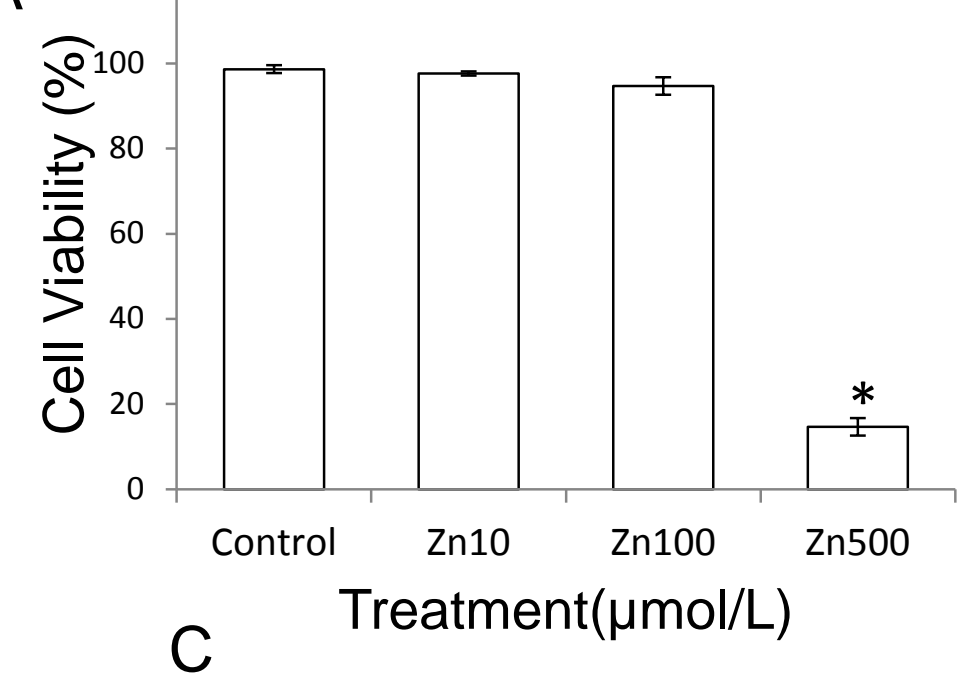

B 120

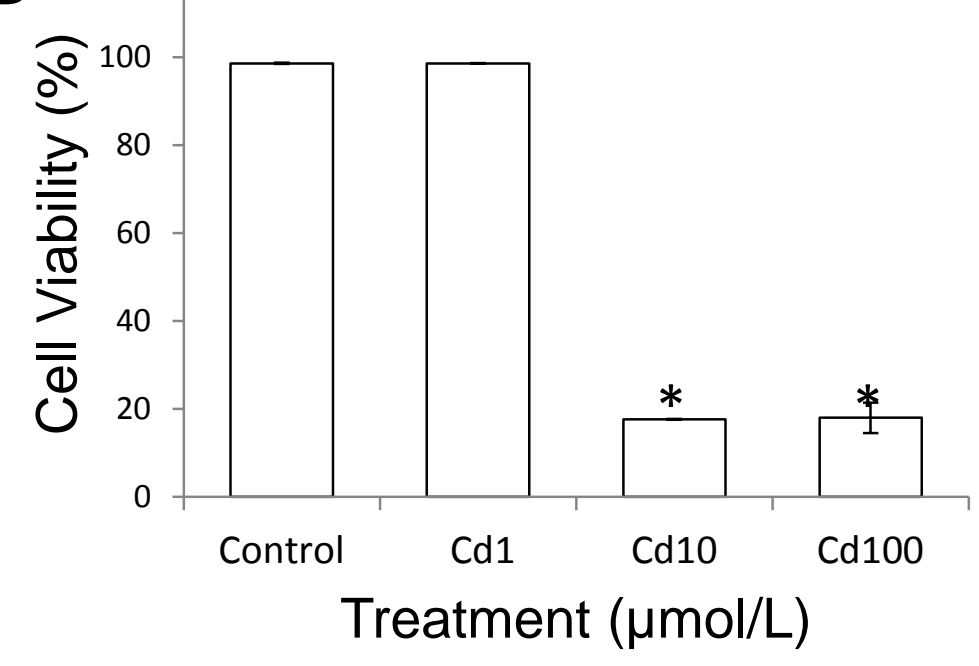

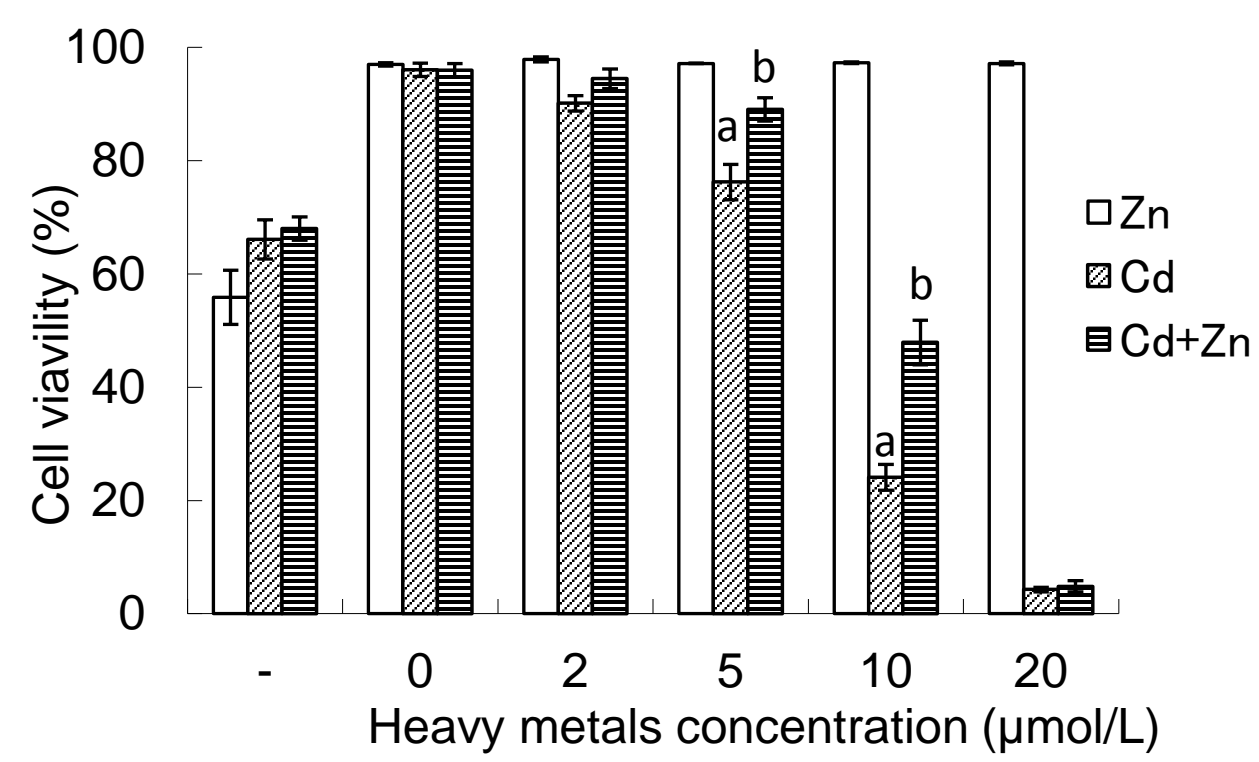

Fig. S1. Cell viability of PC12 cells exposed to different concentration of $\mathrm{Cd}^{2+}(\mathrm{A}), \mathrm{Zn}^{2+}(\mathrm{B})$ and $\mathrm{Cd}^{2+}, \mathrm{Zn}^{2+}$ and both (C) for $48 \mathrm{~h}$. Each experiment was conducted at least three times for reproducibility. Error bars indicate mean \pm SEM $(n=4)$. * denotes significance at $p<0.05$ compared to control. There is also a significant difference $(p<0.05)$ between $a$ and $b$. 
B
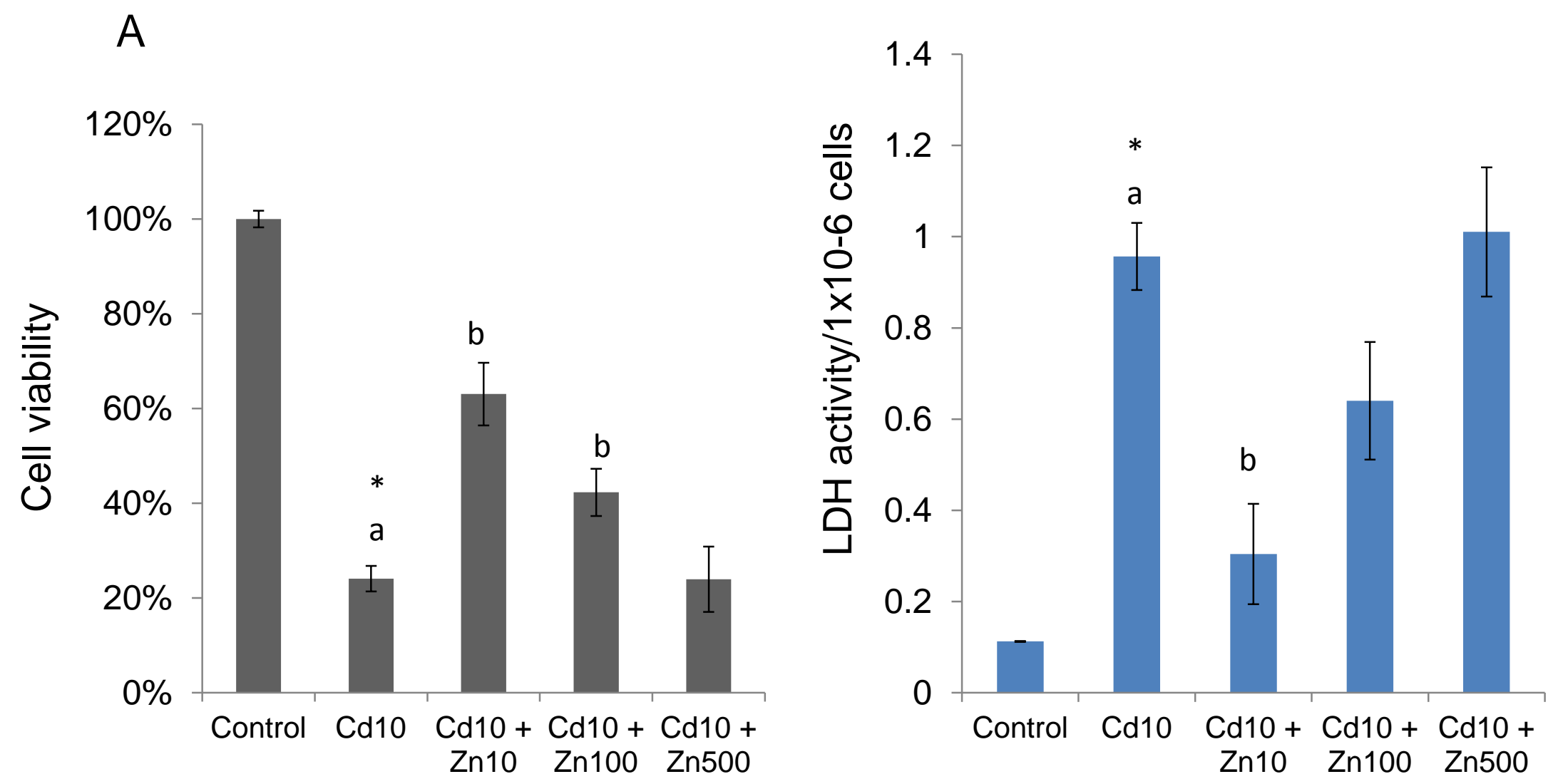

Fig. S2 Viability (A) and LDH activity (B) of HepG2 cells with and without $\mathrm{Cd}^{2+} / \mathrm{Cd}^{2+}+\mathrm{Zn}^{2+}$ treatment at different concentrations after 48-h. Each experiment was conducted three times independently to ensure biological reproducibility. Cells co-exposed to $10 \mu \mathrm{mol} / \mathrm{L}$ $\mathrm{Cd}^{2+}$ and $10-500 \mu \mathrm{mol} / \mathrm{L} \mathrm{Zn}^{2+}$. Error bars indicate the mean $\pm \mathrm{SEM},{ }^{*}$ denotes significance at $p<0.05$ compared to control. There is also a significant difference ( $p$ $<0.05$ ) between $a$ and $b$. 


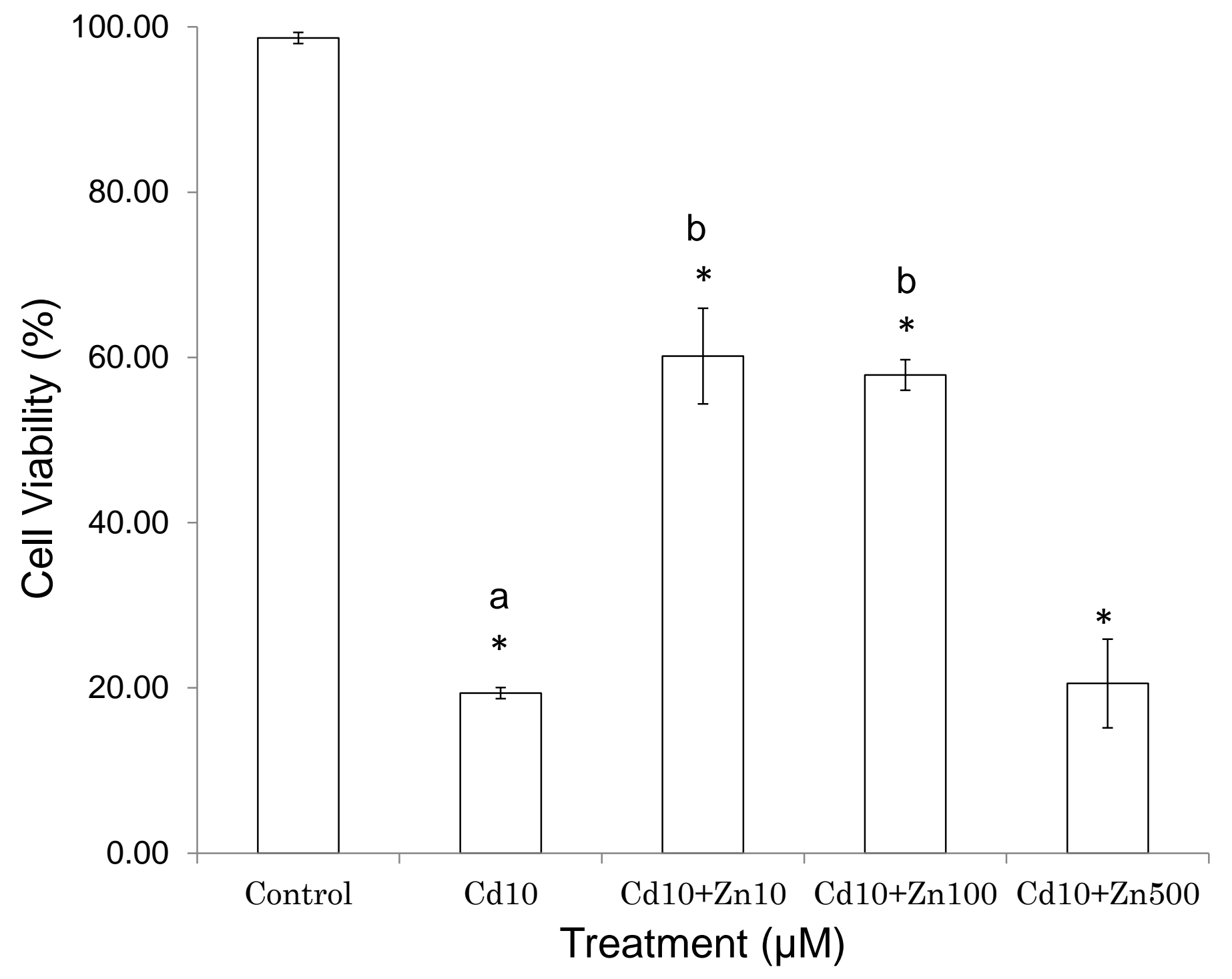

Fig. 1 


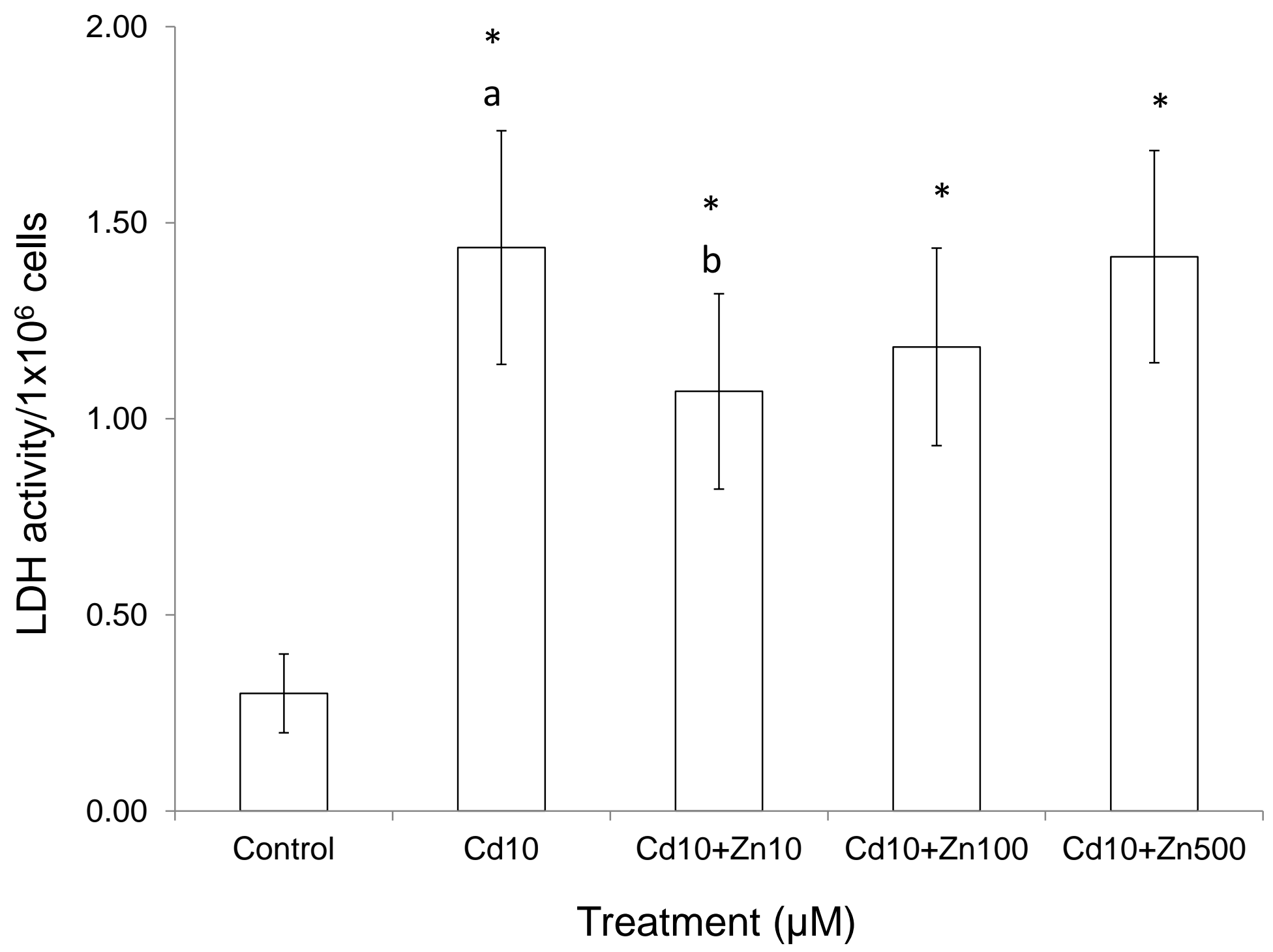

Fig. 2 


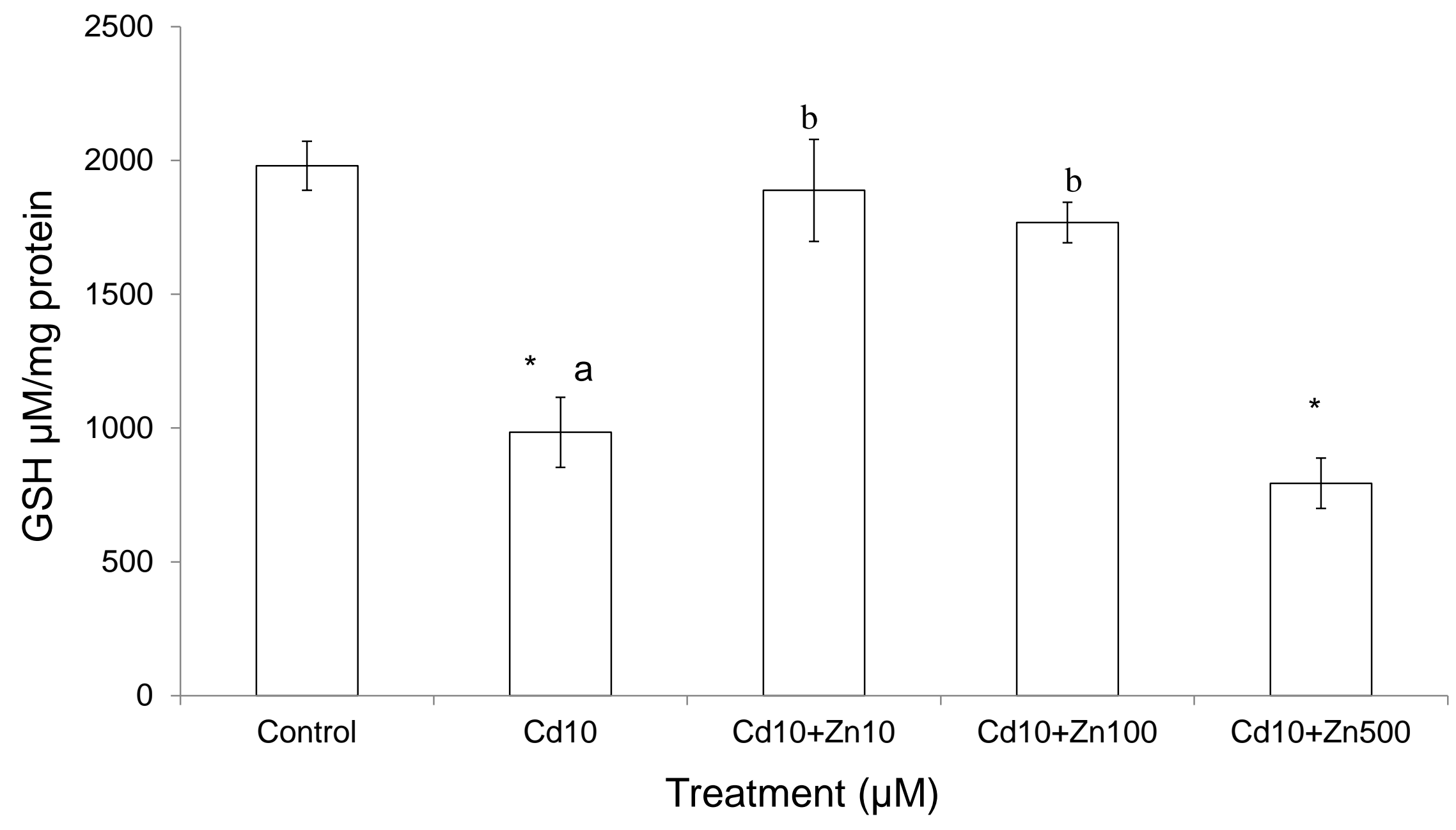

Fig. 3 
A

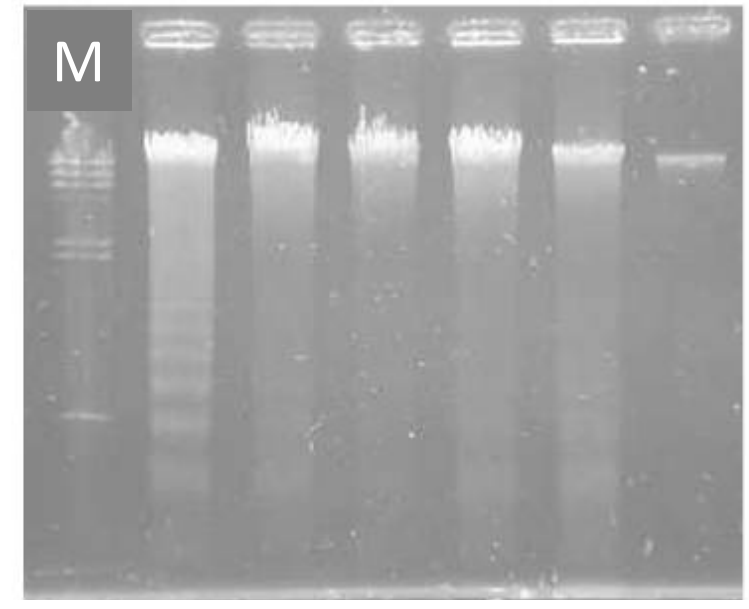

$$
\begin{array}{lcccccc}
\text { FBS } & - & + & + & + & + & + \\
\text { Cd } & 0 & 0 & 2 & 5 & 10 & 20
\end{array}
$$

\section{B}

M

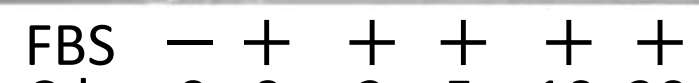

$\begin{array}{lllllll}C d & 0 & 0 & 2 & 5 & 10 & 20\end{array}$

$\begin{array}{lllllll}\mathrm{Zn} & 0 & 0 & 2 & 5 & 10 & 20\end{array}$

Fig. 4

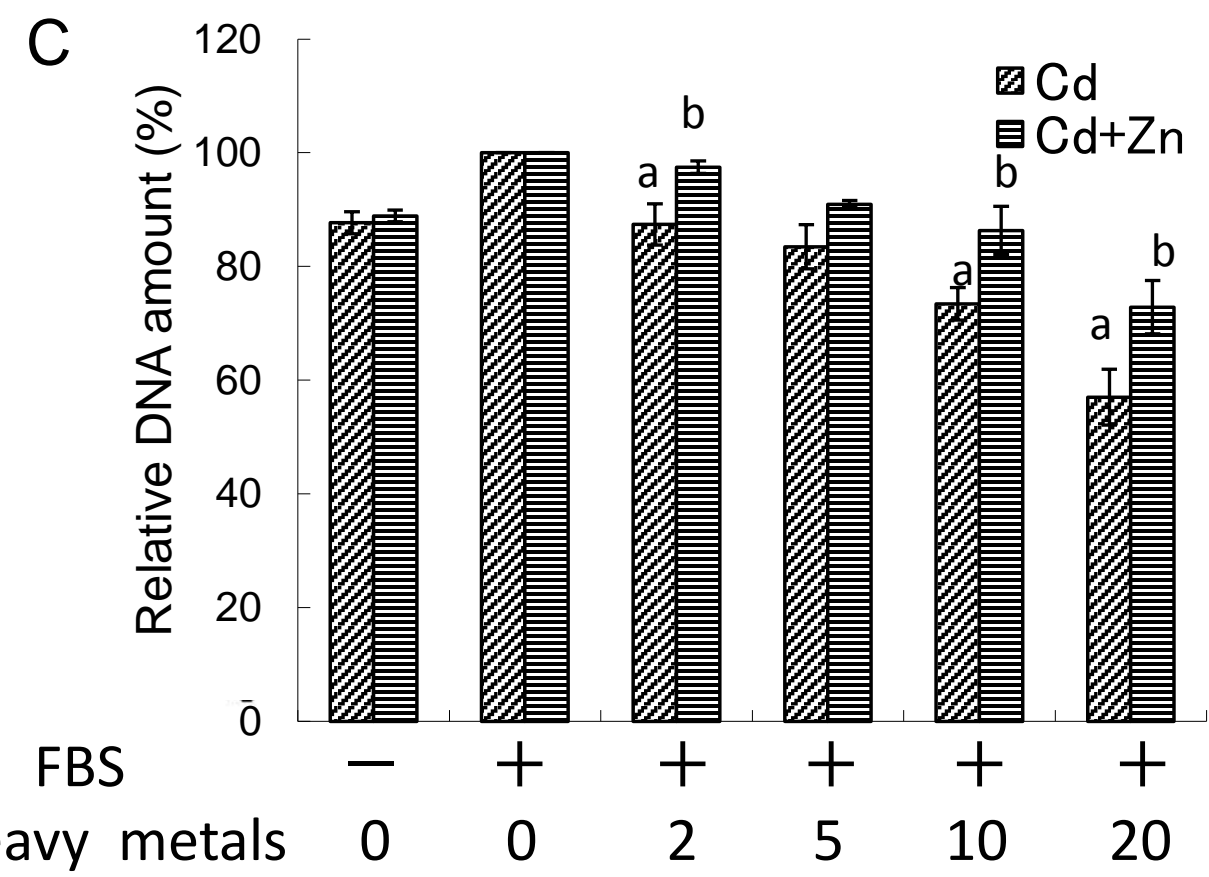



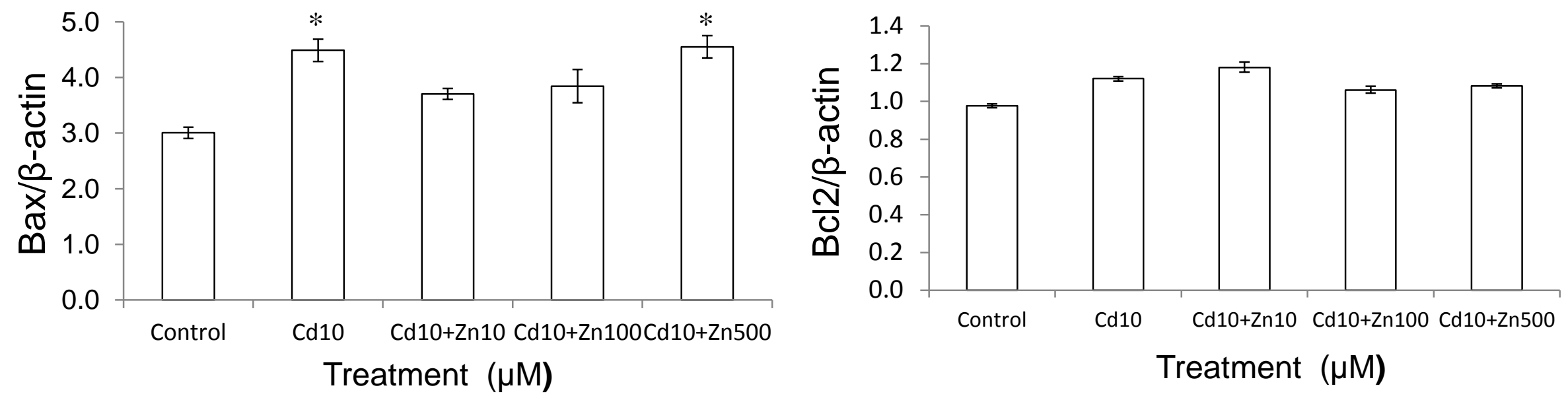

C

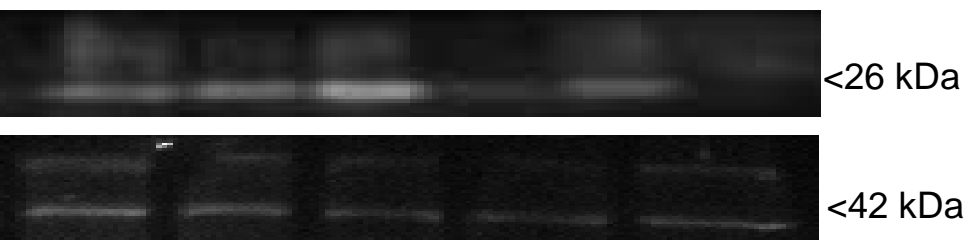

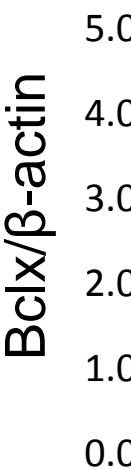

$$
\begin{aligned}
& \begin{array}{l}
5.0 \\
4.0 \\
3.0 \\
2.0 \\
1.0 \\
0.0
\end{array}
\end{aligned}
$$
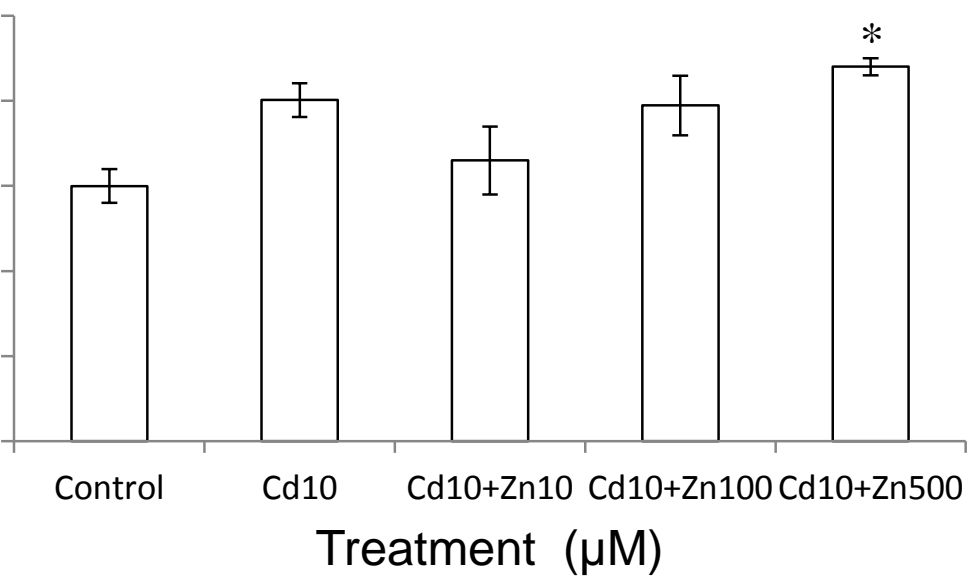

Fig. 5

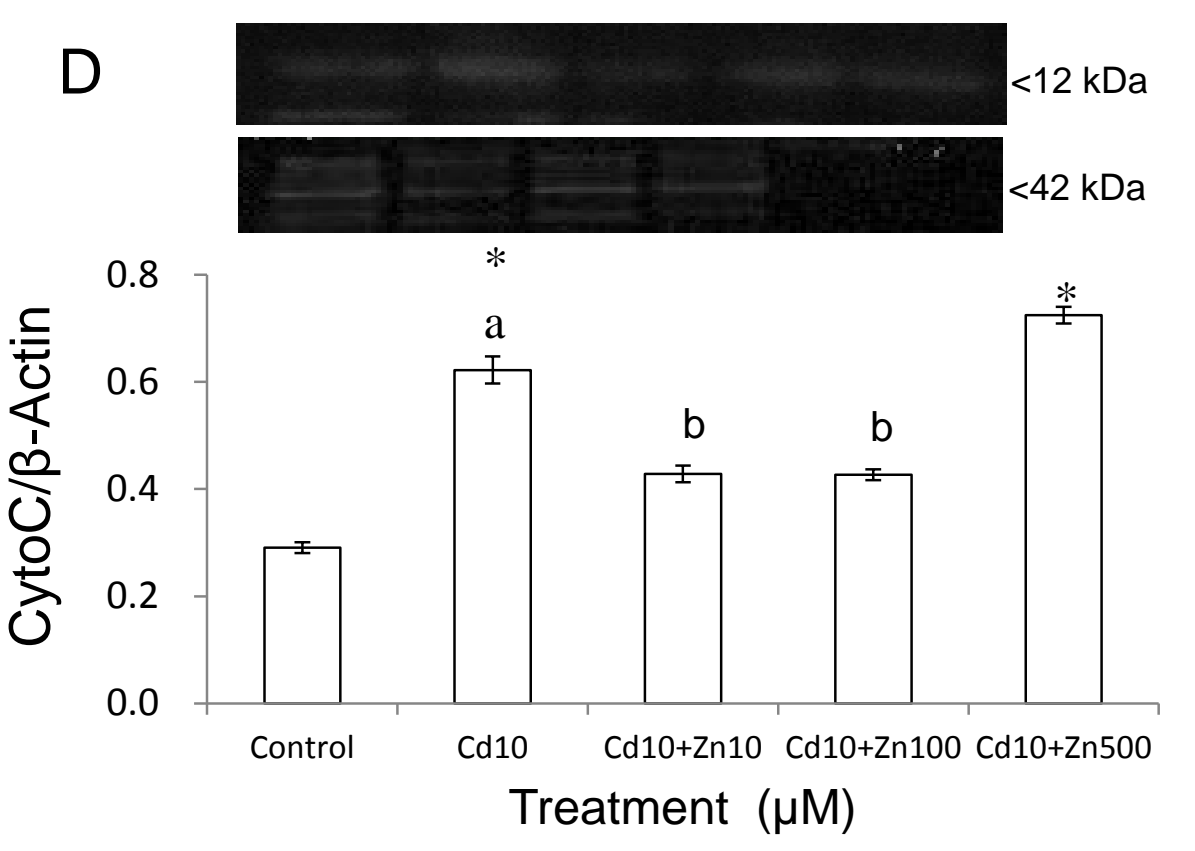




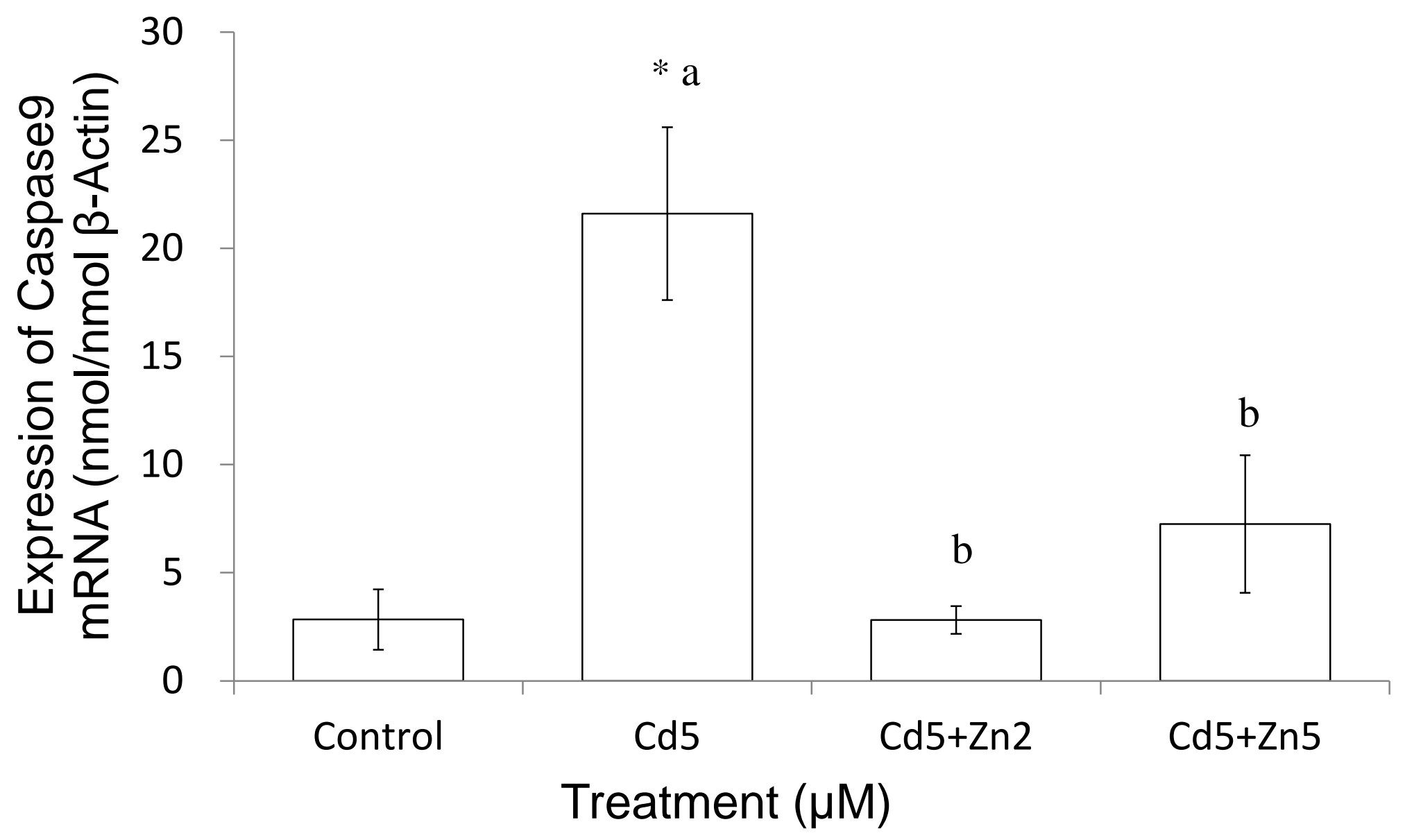

Fig. 6 